\title{
Black shales contamination and depositional paleoenvironment during the Early Aptian OAE 1a in the Eastern Russian Platform
}

\author{
SVETLANA O. Zorina
}

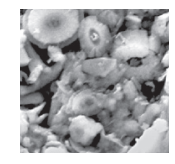

\begin{abstract}
The most pernicious consequences of the Early Aptian Oceanic Anoxic Event (OAE) 1a in the North-Eastern PeriTethys for benthic microfauna were oxygen decrease and the onset of sulphidic conditions, related to toxic enrichment in heavy metals which can be regarded as one of the main causes for biota distress and even their disappearance. Twenty-nine samples from the Tatar-Shatrashany borehole located in the Ulyanovsk-Saratov Trough (Eastern Russian Platform) were studied to estimate the extent of anoxia using trace element redox proxies and pyrite framboid morphology and distribution. The degree of contamination in toxic metals (As, $\mathrm{Cd}, \mathrm{Se}, \mathrm{Pb}, \mathrm{Zn}, \mathrm{Ni}, \mathrm{Mo}, \mathrm{Cu}, \mathrm{V}$, and W) is estimated for the Lower Aptian OAE 1a-related black shales of the Ulyanovsk Formation and compared with the results obtained for the Late Jurassic OAE-related black shales of the Promzino Formation and host mudrocks. The relationships between benthic foraminiferal abundance and diversity and black shales contamination in toxic metals are evaluated. Extreme contamination of the OAE 1a-related black shales in $\mathrm{Mo}$ and $\mathrm{Cd}$ in conjunction with the absence of oxygen could result in conditions not suitable for benthic foraminifers dwelling. The key species Mjatliukaena aptiensis (Mjatl.) is regarded to be one of the toxic-resistant species that successfully recovered from the OAE 1a anoxic stress. Comparing to the Late Jurassic OAE, the integrated data indicate moderately contaminated black shales and mainly dysoxic conditions under which habitat conditions were not completely detrimental for benthic foraminifers. The most toxic-resistant species was Lenticulina infravolgaensis (Furs. et Pol.). - Key words: OAE 1a; Aptian; anoxia; black shales; Peri-Tethys; foraminiferal abundance.
\end{abstract}

ZorinA, S.O. 2022. Black shales contamination and depositional paleoenvironment during the Early Aptian OAE 1a in the Eastern Russian Platform. Bulletin of Geosciences 97(1), 123-140 (6 figures, 6 tables, electronic supplement). Czech Geological Survey, Prague. ISSN 1214-1119. Manuscript received May 24, 2020; accepted in revised form November 8, 2021; published online November 22, 2021; issued January 23, 2022.

Svetlana O. Zorina, Institute of Geology and Petroleum Technologies, Kazan Federal University, 4/5 Kremlyovskaya Str., Kazan, Russian Federation 420008; svzorina@yandex.ru

Late Jurassic-Late Cretaceous is considered a time of increasing temperatures and "greenhouse conditions" (Scotese 2016). This period is marked by several episodes of widespread anoxia and enhanced productivity in the oceans (Jenkyns 2010, Scotese 2014), resulting in black shale deposits known in the Cretaceous as Oceanic Anoxic Events (OAE) (Schlanger \& Jenkyns 1976). The Early Aptian OAE 1a (Selli Event, $\sim 120 \mathrm{Ma}$ ) lasting $\sim 1-1.4$ $\mathrm{Ma}$ (Li et al. 2008, Malinverno et al. 2010) coincided with both the beginning of significant warming and a short-term drop in $\delta^{13} \mathrm{C}$ values in marine carbonates (e.g., Menegatti et al. 1998, Zakharov et al. 2013). The event could be caused by an activation of large igneous provinces (Larson \& Erba 1999, Tejada et al. 2009, Keller et al. 2011, Percival et al. 2021) or release of methane gas hydrate trapped in oceanic sediments (e.g., Jahren et al. 2001, Van Breugel et al. 2007) leading to sudden addition of isotopically light volcanic $\mathrm{CO}_{2}$ to the atmosphere and oceans. Similar events are known from the Jurassic, e.g. the Toarcian anoxic event (French et al. 2014) and the "Late Jurassic anoxic event" (Trabucho-Alexandre et al. 2012, Nozaki et al. 2013).

At the moment, deposits rich in organic matter (OM) are of increasing interest since they are a potential source of hydrocarbons and an indicator for climate and environmental changes, but also may comprise itself a source of greenhouse gases, such as methane (Maksyutova et al. 2018).

There is a general acceptance confirmed by the results from the Tethys, Atlantic, and Pacific oceans, North Sea, Russian Platform, Lower Saxony, and many other basins that major warming characterized OAE 1a (Selli Event), which began before and reached a maximum during initial OAE 1a (e.g., Erba et al. 2010, Zakharov et al. 2013, Bottini et al. 2015). The rest of the OAE 1a interval was marked by subsequent "cold snap", and a further cooling took place when the uppermost part of the organic carbonrich level was deposited (e.g., Bottini et al. 2015). 
Considering the anoxic events have been well studied and described in many studies, the general presentation of the consequences of these events is characterized by temperature maximum, hydrothermal and volcanic driven ocean fertility increase, extensive transgressions, stagnation of hydrodynamic regime of basins, and stratification of water masses, decrease in dissolved oxygen in the water, biotic crisis, and conditions under which the $\mathrm{OM}$ does not oxidize and is preferably preserved in the sediments (Schlanger \& Jenkyns 1976, Jenkyns 2010).

The main feature of benthic foraminiferal assemblages during the OAE $1 \mathrm{a}$ in different regions of the Tethys Ocean is a dramatic decrease in both diversity and abundance or their total absence (Premoli Silva et al. 1999, Friedrich 2010, Moosavizadeh et al. 2014, von Bargen \& Lehmann 2014). Together with the above-mentioned oxygen decrease and wide-spread hydrogen sulphide contamination, the most pernicious outcome for benthic microfauna could be a contamination of sediments by toxic metals (TM) (Murray 2006, Galiakberov et al. 2018).

The degree and extent of toxic-metal pollution in recent sediments as a result of human activities has been one of the main topics studied in environmental geochemistry. In addition to anthropogenic metal inputs, high levels of potentially toxic elements are present in natural geochemical materials, such as $\mathrm{Cd}$, $\mathrm{Mo}$, and other heavy metals in black shales throughout the world (e.g., Atkinson 1967, Vine \& Tourtelot 1970, Lund et al. 1981, Lee et al. 1998, Poňavič et al. 2006, Ketris \& Yudovich 2009).

One of the problems to solve was to estimate the extent of anoxia and the degree of the TM contamination in the Lower Aptian OAE 1a-related black shales from the epeiric sea of the North-Eastern Peri-Tethys (Eastern Russian Platform) and to compare the results with those in the Late Jurassic OAE-related black shales and host mudrocks. The second one concerns the relationships between benthic foraminiferal abundance and diversity and black shales contamination in TM.

Bulk-rock samples of bituminous rocks from two anoxic levels (the Early Aptian Ulyanovsk Formation [Fm] and the Middle Volgian Promzino Fm) from the Tatar-Shatrashany borehole (Eastern Russian Platform) were studied, to address the problem under discussion.

Finally, to generalize the data obtained the task was to provide a paleoenvironmental model for the pre-OAE 1a, OAE 1a, and post-OAE 1a conditions in the NorthEastern Peri-Tethys, including paleoclimate and sea-level fluctuations.

\section{Geologic setting and paleogeography}

Twenty-nine cores of bituminous rocks from two anoxic levels and host mudrocks, $210 \mathrm{~m}$ in total thickness were studied from the Tatar-Shatrashany borehole which was drilled for geological survey purposes in the Republic of Tatarstan, Russian Federation. It is located in the eastern part of European Russia, $70 \mathrm{~km}$ northwest of the city of Ulyanovsk (E 47.383122 ${ }^{\circ}$, N 54.554399 ${ }^{\circ}$ ) (Fig. 1).

Rocks of the Tatar-Shatrashany borehole were deposited on the North-Eastern Peri-Tethys (Eastern Russian Platform) within an epeiric sea acting as a marine strait connecting the Tethys Ocean with the Boreal-Arctic

A

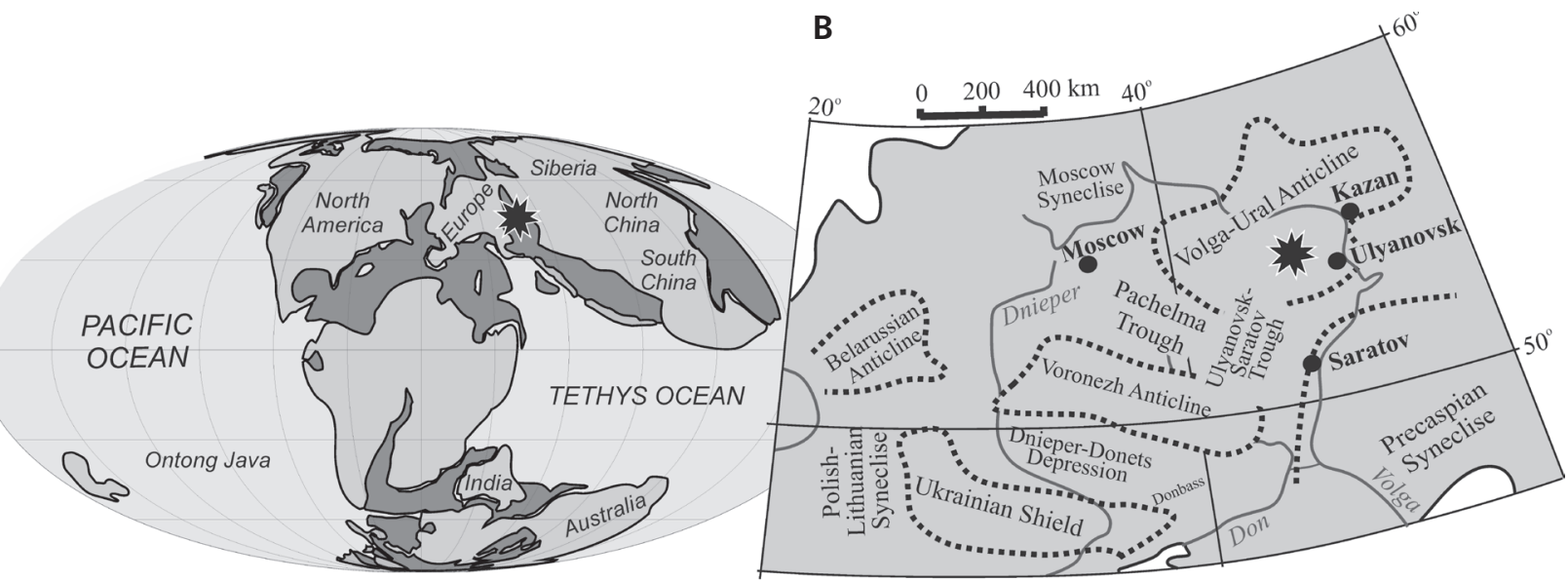

Legend

Anoxic areas

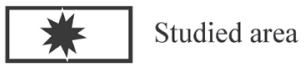

Figure 1. Location of studied area: A - on the Early Aptian paleogeographic map (simplified from Scotese 2014); B - on the tectonic scheme of the Eastern Russian Platform (simplified from Olferiev et al. 2008). 
Figure 2. Upper Jurassic-Lower Cretaceous strata of the TatarShatrashany Borehole (Eastern Russian Platform) (Zorina 2016) and TOC content of rocks (Zorina et al. 2020). Legend: 1 - sandstones; 2 - mudrocks; 3 - marlstones; 4 - black shales; 5 - bituminous mudrocks; 6 - normal polarity; 7 - reverse polarity.

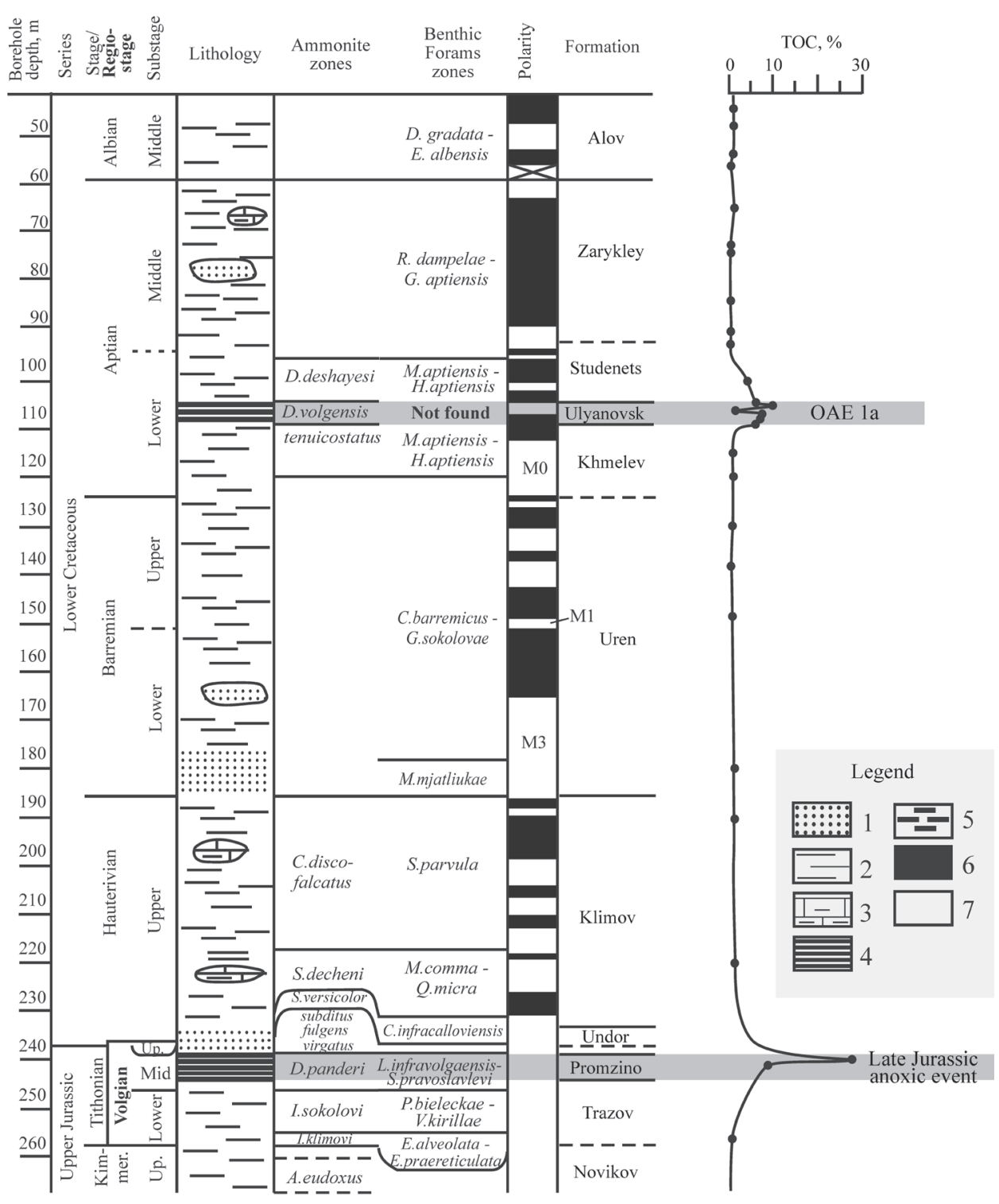

Sea during the Early Aptian (Fig. 1A) (Scotese 2014). Palaeolatitude of the site determined using http://paleolatitude.org for the age of $120 \mathrm{Ma}$ is $45.34^{\circ} \mathrm{N}$. Seawater palaeotemperatures calculated from oxygen isotopic analyses of aragonite bivalve shells and heteromorphic ammonites from the Lower Aptian black shales of the Eastern Russian Platform showed extremely high values 24-33.2 ${ }^{\circ} \mathrm{C}$ (Zakharov et al. 2013).

Tectonically, the section belongs to the UlyanovskSaratov Trough (Fig. 1B) which stretches in the eastern part of the Russian Platform for more than $850 \mathrm{~km}$ being filled with Middle Jurassic-Paleogene deposits (Olferiev et al. 2008).

The Upper Jurassic-Lower Cretaceous strata of the Tatar-Shatrashany borehole consist of the Upper Kimmeridgian-Middle Volgian (Upper Tithonian) and the Upper Hauterivian-Middle Albian successions (Zorina
2014, 2016). The Upper Jurassic sequence comprises bluish-gray and light gray carbonate mudrocks and marlstones, up to $25 \mathrm{~m}$ in thickness (Upper Kimmeridgian Novikov Fm and Lower-Middle Volgian Trazov Fm) which are overlapped by black shales of the Middle Volgian Promzino Formation. The Promzino Fm consists of dark brown thinly laminated bituminous shales and bituminous mudrocks, $6 \mathrm{~m}$ in thickness. Benthic foraminifers from the Upper Jurassic Lenticulina infravolgaensis - Saracenaria pravoslavlevi Zone are found in the Promzino black shales (Fig. 2). It is overlaid by greenishgray sandstones, with phosphorite pebbles, $0-1.5 \mathrm{~m}$ in thickness (Upper Volgian Undor Fm) (Zorina 2007) (Fig. 2).

The total organic carbon (TOC) content in the Promzino black shales varies from 8.4 to $27.3 \%$ (Zorina 2009, 2014) (Fig. 2). This organic carbon-rich formation is regarded as a manifestation of the Late Jurassic OAE, 
the sedimentary expressions of which are reported from different regions of the world; in particular, the Bazhenov Fm of the West Siberian Platform (Ulmishek 2003) and voluminous sulphide deposition in Panthalassa (Nozaki et al. 2013).

The Lower Cretaceous (Upper Hauterivian-Middle Aptian and Middle Albian) deposits are presented by highly bioturbated dark gray, mostly carbonate-free mudrocks, with rare interlayers of quartz sandstones. The thickness of the Upper Hauterivian Klimov Fm is more than $60 \mathrm{~m}$, of the Barremian Uren Fm is more than $40 \mathrm{~m}$, of the Aptian Khmelev, Ulyanovsk, Studenets, and Zarykley formations is about $90 \mathrm{~m}$, and of the Albian Alov Fm is up to $130 \mathrm{~m}$ (Fig. 2, Tab. 1).

Importantly, the Lower Aptian black shales (Ulyanovsk Fm), $4.2 \mathrm{~m}$ in thickness (Fig. 2), are reported to correlate with OAE 1a (Gavrilov et al. 2002, Zorina et al. 2017). The Ulyanovsk Fm consists of dark brown thinly-laminated bituminous mudrocks $(1-5 \mathrm{~mm}$ thick) with pyrite interlayers, composed of high-carbon closelypacked pyrite framboids indicating dysoxic conditions (Zorina et al. 2017). The TOC values vary between $6.1-10.0 \%$. The black shales are interbedded by concretionary limestone, $1.2 \mathrm{~m}$ in thickness, with the TOC content of $1.3 \%$ (Fig. 2) (Zorina et al. 2020). Benthic foraminifers are abundant in the succession studied, except the Lower Aptian black shales where they were not found (Fig. 2).

\section{Methods}

Trace element analyses (V, Ni, Cu, Zn, As, Se, Mo, Cd, $\mathrm{W}, \mathrm{Pb}, \mathrm{U}$, and $\mathrm{Th}$ ) of twenty-nine bulk-rock samples from the Tatar-Shatrashany core were undertaken using an inductively coupled plasma mass spectrometer iCAP Qc (ThermoFisher Scientific, Germany). The obtained concentration values were recalculated to the initial concentration considering the empty sample, sample mass, and dilution of the solution. Additionally, concentrations of $\mathrm{Al}$ were investigated in the same samples that were used for ICP-MS using the S8 Tiger X-ray fluorescence wave-dispersion spectrometer (Bruker, Germany). The obtained spectrum was processed by the fundamental parameter's method, and automatic recognition errors.

Redox-sensitive element concentrations and their ratios (Mo, Mo/TOC, U/Th, $\mathrm{U}_{\mathrm{au}}$ expressed as $\mathrm{U}-\mathrm{Th} / 3$, $\mathrm{V} / \mathrm{Al}, \mathrm{U} / \mathrm{Al}, \mathrm{Mo} / \mathrm{Al}, \mathrm{TOC} / \mathrm{P}_{\text {tot }}$ ) were used for estimating the degree of the anoxic condition.

Scanning electron microscope method was applied to determine pyrite framboids in six samples from both Ulyanovsk and Promzino black shales and when present, their size distribution was measured. The surface of the natural sample chip was examined with an XL-30 ESEM scanning electron microscope. Microprobe analysis of the element composition at selected points of the sample was carried out with an energy-dispersive X-ray spectrometer.

The analyses were conducted at the Institute of Geology and Oil and Gas Technologies, Kazan Federal University (Russia).

The quantitative treatment of the diameters of pyrite framboids was used as an additional tool for the reconstruction of the redox conditions of the marine environment (Wignall et al. 2005, Bond \& Wignall 2010).

To estimate the extent of sediment contamination in $\mathrm{TM}$, ten trace elements identified as highly hazardous (As, $\mathrm{Cd}, \mathrm{Se}, \mathrm{Pb}, \mathrm{Zn}$ ), moderately hazardous ( $\mathrm{Ni}, \mathrm{Mo}, \mathrm{Cu}$ ), and low hazardous $(\mathrm{V}, \mathrm{W})$ metals according to Russian ecological Standard (Vodyanitskii 2012) were taken for further evaluation.

Geo-accumulation index $\left(\mathrm{I}_{\mathrm{geo}}\right)$ is used as a quantitative measure of heavy metal pollution in aquatic sediments (Müller 1969) calculated by comparing current concentrations with geochemical background value metal in the Upper Continental Crust (Rudnick \& Gao 2003), where, $C_{n}-$ concentration of metal in sediment; $B_{n}-$ background concentration of metal in the Upper Continental Crust (Rudnick \& Gao 2003); 1.5 - a factor used to minimize the effect of possible variations in the background values which may be due to lithological variations in the sediments.

According to Müller (1969) seven different classes of $\mathrm{I}_{\text {geo }}$ values are established (Tab. 1).

Table 1. Different classes of $I_{\text {geo }}$ values (Müller 1969).

\begin{tabular}{lll}
\hline Class & $\mathrm{I}_{\text {geo }}$ values & Sediment quality \\
\hline 0 & $\leq 0$ & Uncontaminated \\
1 & $0-1$ & Uncontaminated to moderately contaminated \\
2 & $1-2$ & Moderately contaminated \\
3 & $2-3$ & Moderately to heavily contaminated \\
4 & $3-4$ & Heavily contaminated \\
5 & $4-5$ & Heavily to extremely contaminated \\
6 & $\geq 5$ & Extremely contaminated \\
\hline
\end{tabular}

Measurement of foraminiferal abundance and diversity was provided using the results of microfaunal analysis (Zorina \& Startseva 2010) of twenty-nine core samples from the same depth as those for geochemical analyses. The number of species of benthic foraminifers per $100 \mathrm{~g}$ of rock for each sample was taken from the microfaunal analysis performed by the paleontologist G.N. Startseva, and recalculated to the number of specimens per $1 \mathrm{~m}^{2}$. Both data were used in constructing quantitative curves in order to study foraminiferal abundance and diversity throughout the section. 


\section{Results}

\section{Trace elements redox proxies}

Raw geochemical data including the concentrations of $\mathrm{TM}$ and $\mathrm{Al}$ for the Upper Jurassic-Lower Cretaceous rocks from the Tatar-Shatrashany section are given in Table 2. The black shales of the Promzino and Ulyanovsk formations show considerable Mo and Mo/TOC enrichment (Tab. 3, Fig. 3), with Promzino shales having Mo values in the 22-24 ppm range, whereas the Ulyanovsk shales have higher values, some in excess of $140 \mathrm{ppm}$. The lowest Mo concentrations (5.7 ppm or less) occur in the organic carbon-poor Novikov and Trazov marls and Klimov-Alov mudrocks. The Mo/TOC ratios of the Ulyanovsk shales are of the highest values varying from 10.3 to 41.6, whereas the Promzino shales display much lower values in the $0.8-2.9$ range. The host organic carbonpoor rocks have a wide range of values, thus mudrocks from the Lower Cretaceous formations show Mo/TOC values in the 0.4-3.1 range, the Upper Jurassic marls display the 3-9.1 range.

Both Promzino and Ulyanovsk black shales have $\mathrm{U} / \mathrm{Th}$ ratios from 1.4 to 2.6 , while the host marls and mudrocks show values in the $0.1-0.5$ range (Table 3; Fig. 3).

The $\mathrm{U}_{\mathrm{au}}$ content in the Promzino black shales is found in the 11.1-11.9 ppm range, while the Ulyanovsk black shales show $5.7-17.8 \mathrm{ppm}$. It is noteworthy that the organic carbon-poor rocks reveal consistently low values of the $\mathrm{U}_{\mathrm{au}}$ about -2.4-2.8 ppm (Tab. 3, Fig. 3).

Both organic carbon-rich formations display V/Al, $\mathrm{U} / \mathrm{Al}$, and $\mathrm{Mo} / \mathrm{Al}$ ratios in the 34.7-48.3, 1.8-4.5, and 26.5-126.5 ranges, respectively, whereas organic carbonpoor strata show these ratios in the 15.4-28.8, 0.2-1.0, and 2.2-72.2 ranges, respectively (Tab. 3, Fig. 3).

The Promzino and Ulyanovsk black shales show TOC/P ratio in the 74.6-112 and 26.5-125 ranges, respectively whereas the host mudrocks display much lower values in the 2.2-72.2 range (Tab. 3, Fig. 3).

\section{Pyrite framboids shape and distribution}

Pyrite framboids are found in both Promzino and Ulyanovsk black shales (Fig. 4). Most framboids have close-packed shape, but the Promzino black shales contain both close-packed and disintegrating framboids (Fig. 4).

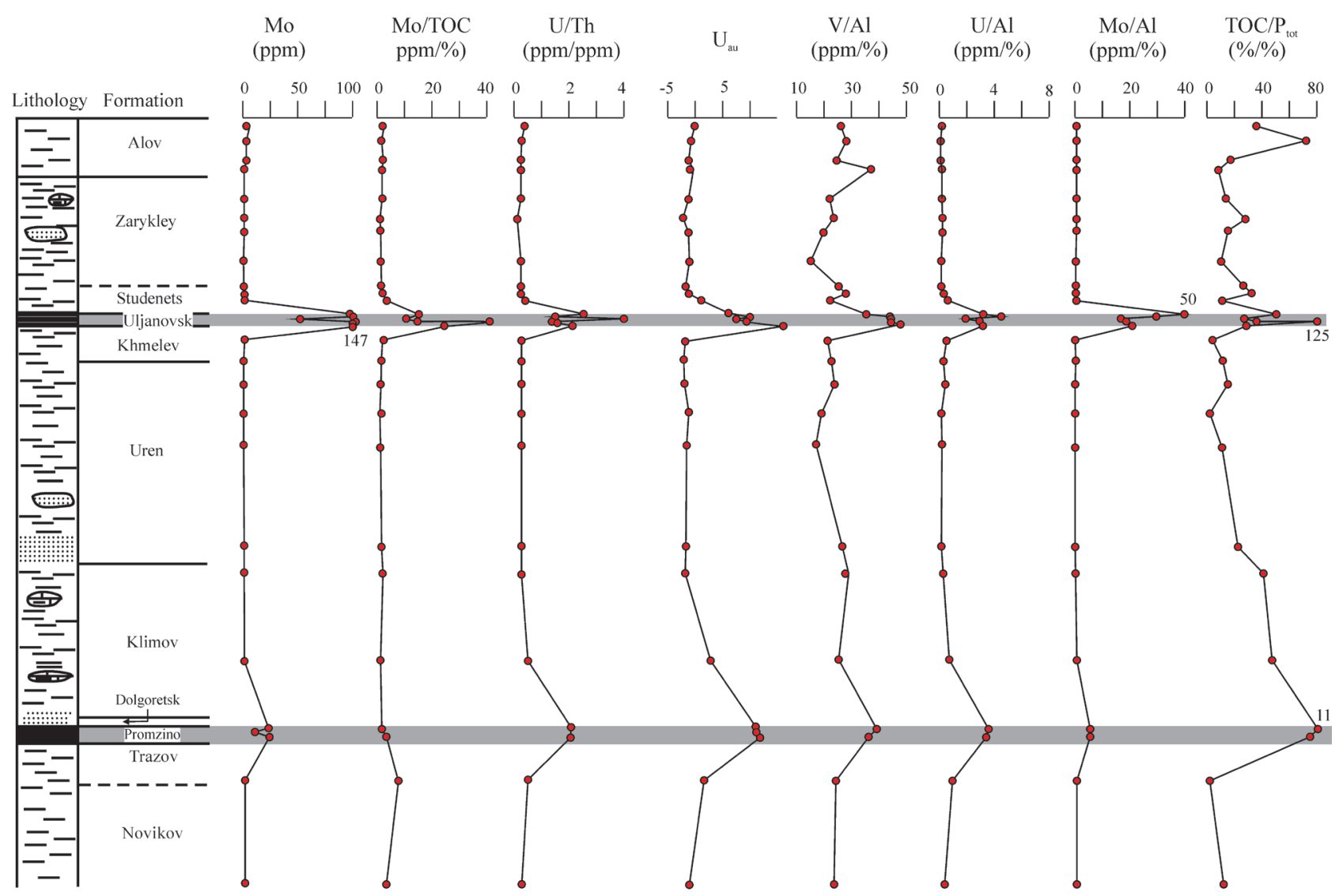

Figure 3. Stratigraphic variations of redox proxies for the Tatar-Shatrashany section. Gray stripes trace the organic carbon-rich intervals. 


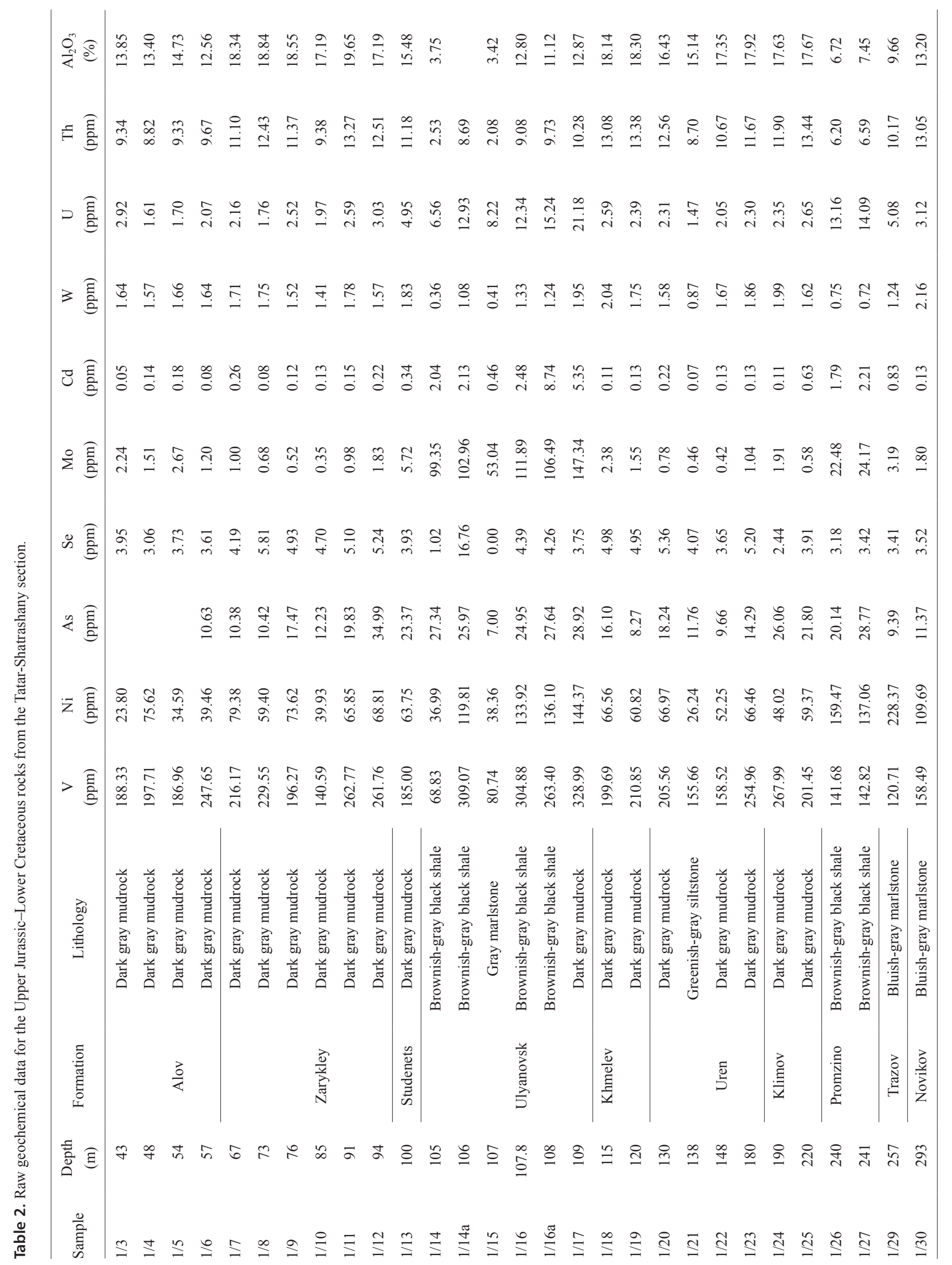


Table 3. Estimated redox proxies for the Upper Jurassic-Lower Cretaceous rocks from the Tatar-Shatrashany section. Gray intervals correspond to black shales.

\begin{tabular}{|c|c|c|c|c|c|c|c|c|}
\hline Sample & $\begin{array}{c}\text { Mo } \\
(\mathrm{ppm})\end{array}$ & $\begin{array}{l}\mathrm{Mo} / \mathrm{TOC} \\
(\mathrm{ppm} / \%)\end{array}$ & $\begin{array}{c}\mathrm{U} / \mathrm{Th} \\
(\mathrm{ppm} / \mathrm{ppm})\end{array}$ & $\mathrm{U}_{\mathrm{au}}$ & $\begin{array}{c}\mathrm{V} / \mathrm{Al} \\
(\mathrm{ppm} / \%)\end{array}$ & $\begin{array}{c}\mathrm{U} / \mathrm{Al} \\
(\mathrm{ppm} / \%)\end{array}$ & $\begin{array}{c}\mathrm{Mo} / \mathrm{Al} \\
(\mathrm{ppm} / \%)\end{array}$ & $\begin{array}{c}\mathrm{TOC} / \mathrm{P}_{\text {tot }} \\
(\% / \%)\end{array}$ \\
\hline $1 / 3$ & 2.2 & 1.7 & 0.3 & -0.2 & 25.7 & 0.4 & 0.3 & 38.7 \\
\hline $1 / 4$ & 1.5 & 0.9 & 0.2 & -1.3 & 27.9 & 0.2 & 0.2 & 72.2 \\
\hline $1 / 5$ & 2.7 & 1.6 & 0.2 & -1.4 & 24.0 & 0.2 & 0.3 & 18.3 \\
\hline $1 / 6$ & 1.2 & 0.8 & 0.2 & -1.2 & 37.3 & 0.3 & 0.2 & 7.4 \\
\hline $1 / 7$ & 1.0 & 0.7 & 0.2 & -1.5 & 22.3 & 0.2 & 0.1 & 16.5 \\
\hline $1 / 8$ & 0.7 & 0.4 & 0.1 & -2.4 & 23.0 & 0.2 & 0.1 & 26.2 \\
\hline $1 / 9$ & 0.5 & 0.4 & 0.2 & -1.3 & 20.0 & 0.3 & 0.1 & 17.1 \\
\hline $1 / 10$ & 0.4 & 0.4 & 0.2 & -1.2 & 15.4 & 0.2 & 0.0 & 9.7 \\
\hline $1 / 11$ & 1.0 & 0.7 & 0.2 & -1.8 & 25.3 & 0.2 & 0.1 & 25.6 \\
\hline $1 / 12$ & 1.8 & 1.1 & 0.2 & -1.1 & 28.8 & 0.3 & 0.2 & 31.5 \\
\hline $1 / 13$ & 5.7 & 2.2 & 0.4 & 1.2 & 22.6 & 0.6 & 0.7 & 11.7 \\
\hline $1 / 14$ & 99.4 & 15.4 & 2.6 & 5.7 & 34.7 & 3.3 & 50.0 & 50.1 \\
\hline $1 / 14 \mathrm{a}$ & 103.0 & 10.3 & 1.5 & 10.0 & & & & \\
\hline $1 / 15$ & 53.0 & 41.6 & 4.0 & 7.5 & 44.6 & 4.5 & 29.3 & 26.5 \\
\hline $1 / 16$ & 111.9 & 14.8 & 1.4 & 9.3 & 45.0 & 1.8 & 16.5 & 125.0 \\
\hline $1 / 16 a$ & 106.5 & 14.4 & 1.6 & 12.0 & 44.7 & 2.6 & 18.1 & 35.8 \\
\hline $1 / 17$ & 147.3 & 24.2 & 2.1 & 17.8 & 48.3 & 3.1 & 21.6 & 28.9 \\
\hline $1 / 18$ & 2.4 & 2.4 & 0.2 & -1.8 & 20.8 & 0.3 & 0.2 & 3.6 \\
\hline $1 / 19$ & 1.6 & 1.4 & 0.2 & -2.1 & 21.8 & 0.2 & 0.2 & 11.5 \\
\hline $1 / 20$ & 0.8 & 0.8 & 0.2 & -1.9 & 23.6 & 0.3 & 0.1 & 16.3 \\
\hline $1 / 21$ & 0.5 & 1.5 & 0.2 & -1.4 & 19.4 & 0.2 & 0.1 & 3.7 \\
\hline $1 / 22$ & 0.4 & 0.5 & 0.2 & -1.5 & 17.3 & 0.2 & 0.0 & 10.2 \\
\hline $1 / 23$ & 1.0 & 0.8 & 0.2 & -1.6 & 26.9 & 0.2 & 0.1 & 22.2 \\
\hline $1 / 24$ & 1.9 & 1.5 & 0.2 & -1.6 & 28.7 & 0.3 & 0.2 & 40.6 \\
\hline $1 / 25$ & 4.0 & 3.1 & 0.5 & 2.8 & 25.3 & 0.8 & 0.4 & 50.5 \\
\hline $1 / 26$ & 22.5 & 0.8 & 2.1 & 11.1 & 39.8 & 3.7 & 6.3 & 112.2 \\
\hline $1 / 27$ & 24.2 & 2.9 & 2.1 & 11.9 & 36.2 & 3.6 & 6.1 & 74.6 \\
\hline $1 / 29$ & 3.2 & 9.1 & 0.5 & 1.7 & 23.6 & 1.0 & 0.6 & 2.2 \\
\hline $1 / 30$ & 1.8 & 3.0 & 0.2 & -1.2 & 22.7 & 0.4 & 0.3 & 13.9 \\
\hline
\end{tabular}

Pyrite framboid distributions are shown in Table 4 and their size is plotted in the graphic log (Fig. 4). The samples from the Lower Aptian OAE-1a reveal mean diameters of pyrite framboids between $6.8 \mu \mathrm{m}$ and $8.1 \mu \mathrm{m}$ and standard deviation $1.7-2.2 \mu \mathrm{m}$. Whereas, pyrite framboids found in the Middle Volgian black shales display higher mean diameters $(7.2-7.9 \mu \mathrm{m})$ and standard deviation $(2.8-3.0 \mu \mathrm{m})$.

\section{Geoaccumulation index}

The obtained $\mathrm{I}_{\text {geo }}$ values revealed that all the samples from the organic carbon-poor host rocks fell within the uncontaminated to moderately contaminated categories by $\mathrm{Pb}, \mathrm{Zn}, \mathrm{Ni}, \mathrm{Cu}$, and $\mathrm{V}$ (Tab. 5, Fig. 5). But, the Middle Volgian Promzino black shales fell within the 
Table 4. Pyrite framboid distributions in the upper Middle Volgian and Lower Aptian black shales from the Tatar-Shatrashany section.

\begin{tabular}{|c|c|c|c|c|c|c|c|c|c|}
\hline \multirow[b]{2}{*}{ Substage } & \multirow[b]{2}{*}{ Formation } & \multirow[b]{2}{*}{ Sample } & \multirow[b]{2}{*}{ Lithology } & \multirow{2}{*}{$\begin{array}{l}\text { Number } \\
\text { of framboids }\end{array}$} & \multicolumn{5}{|c|}{ Framboid diameter $(\mu \mathrm{m})$} \\
\hline & & & & & Max & Min & Mean & $\begin{array}{l}\text { Standard } \\
\text { deviation }\end{array}$ & $\begin{array}{c}\text { Redox } \\
\text { conditions }\end{array}$ \\
\hline \multirow{3}{*}{$\begin{array}{l}\text { Lower } \\
\text { Aptian }\end{array}$} & \multirow{3}{*}{ Ulyanovsk } & $1 / 14$ & Black shales & 38 & 8.6 & 7.9 & 8.1 & 1.7 & Anoxic \\
\hline & & $1 / 16$ & Black shales & 47 & 8.2 & 7.4 & 7.6 & 1.8 & Anoxic \\
\hline & & $1 / 17$ & Black shales & 55 & 7.1 & 6.2 & 6.8 & 2.2 & Anoxic \\
\hline \multirow{3}{*}{$\begin{array}{l}\text { Middle } \\
\text { Volgian }\end{array}$} & \multirow{3}{*}{ Promzino } & $1 / 26$ & Oil shales & 25 & 9.4 & 6.5 & 7.2 & 2.0 & Anoxic \\
\hline & & $1 / 27$ & Black shales & 32 & 8.6 & 6.8 & 7.9 & 3.8 & Dysoxic \\
\hline & & $1 / 27 \mathrm{a}$ & Black shales & 23 & 9.7 & 7.3 & 7.8 & 3.0 & Dysoxic \\
\hline
\end{tabular}

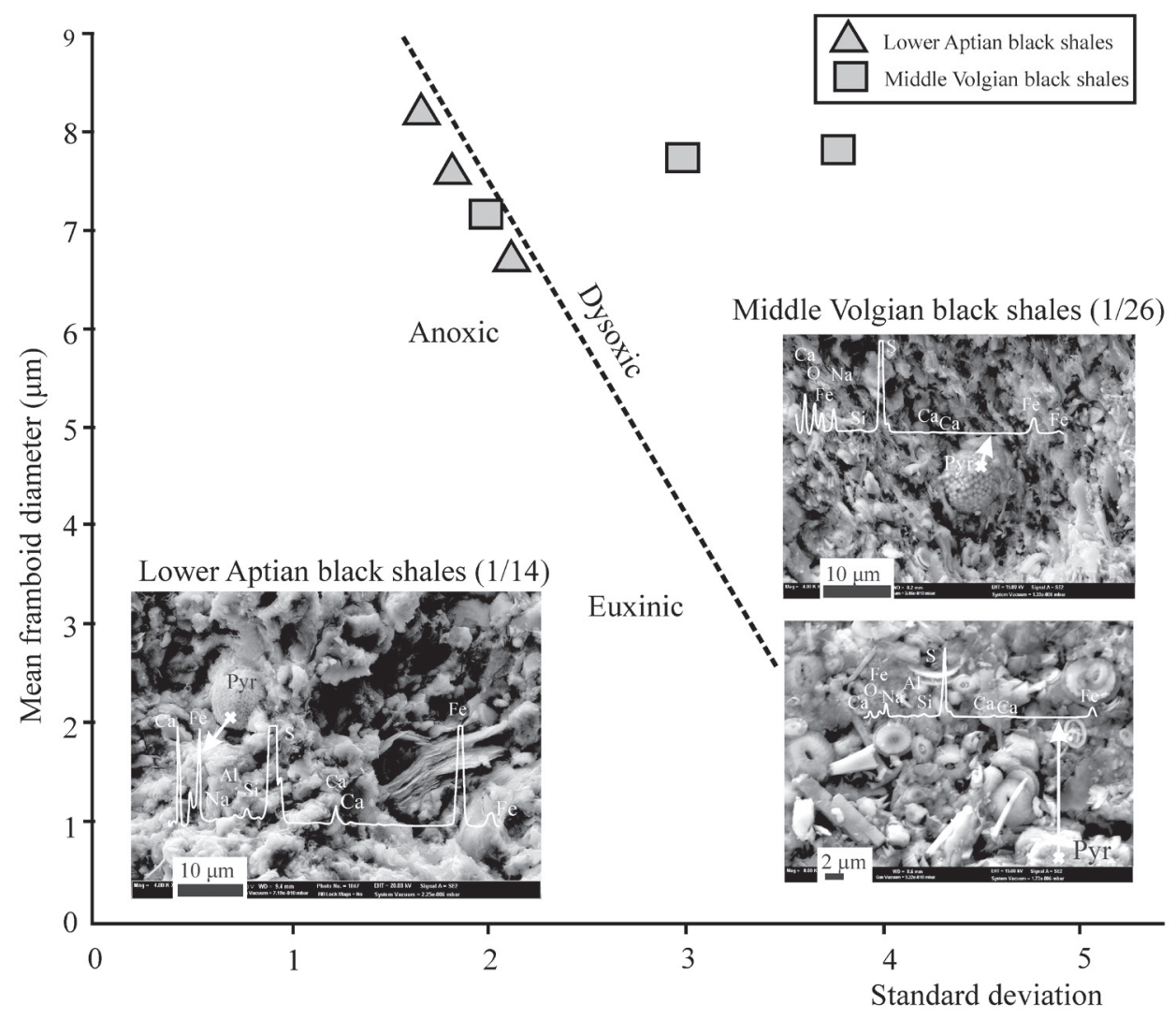

Figure 4. Mean versus standard deviation plot of pyrite framboid data from the Lower Aptian and Middle Volgian black shales of the Tatar-Shatrashany section (Bond \& Wignal 2010). SEM images and EDS of close-packed (samples $1 / 14$ and 1/26) and disintegrated (sample 1/26) pyrite framboid.

heavily to extremely contaminated categories by $\mathrm{Cd}$ and Mo (samples 1/26 and 1/27), while the Lower Aptian black shales (samples 1/14-1/17) showed the extreme contamination by $\mathrm{Cd}$ and Mo as well (Fig. 5).

\section{Benthic foraminiferal diversity and abundance}

A rich complex of benthic foraminifers was found in the study section (Zorina \& Startseva 2010) for which a total number of specimens (per $1 \mathrm{~m}^{2}$ ) and a number of species in the sample are counted (Tab. 6, Fig. 5). The highest number of specimens and number of species (5680 and 14, respectively) occur in the organic carbon-poor Novikov marls and Klimov-Uren mudrocks (1400-3240 and 3-9, respectively). The Promzino and Ulyanovsk black shales show considerable low values of these two parameters varying for the number of specimens in the 0-1400 and 0-520 ranges, respectively, and for the number of species in the $0-5$ and $0-1$ ranges, respectively. Noteworthy, most samples from the Ulyanovsk formation contain no benthic foraminifers. 


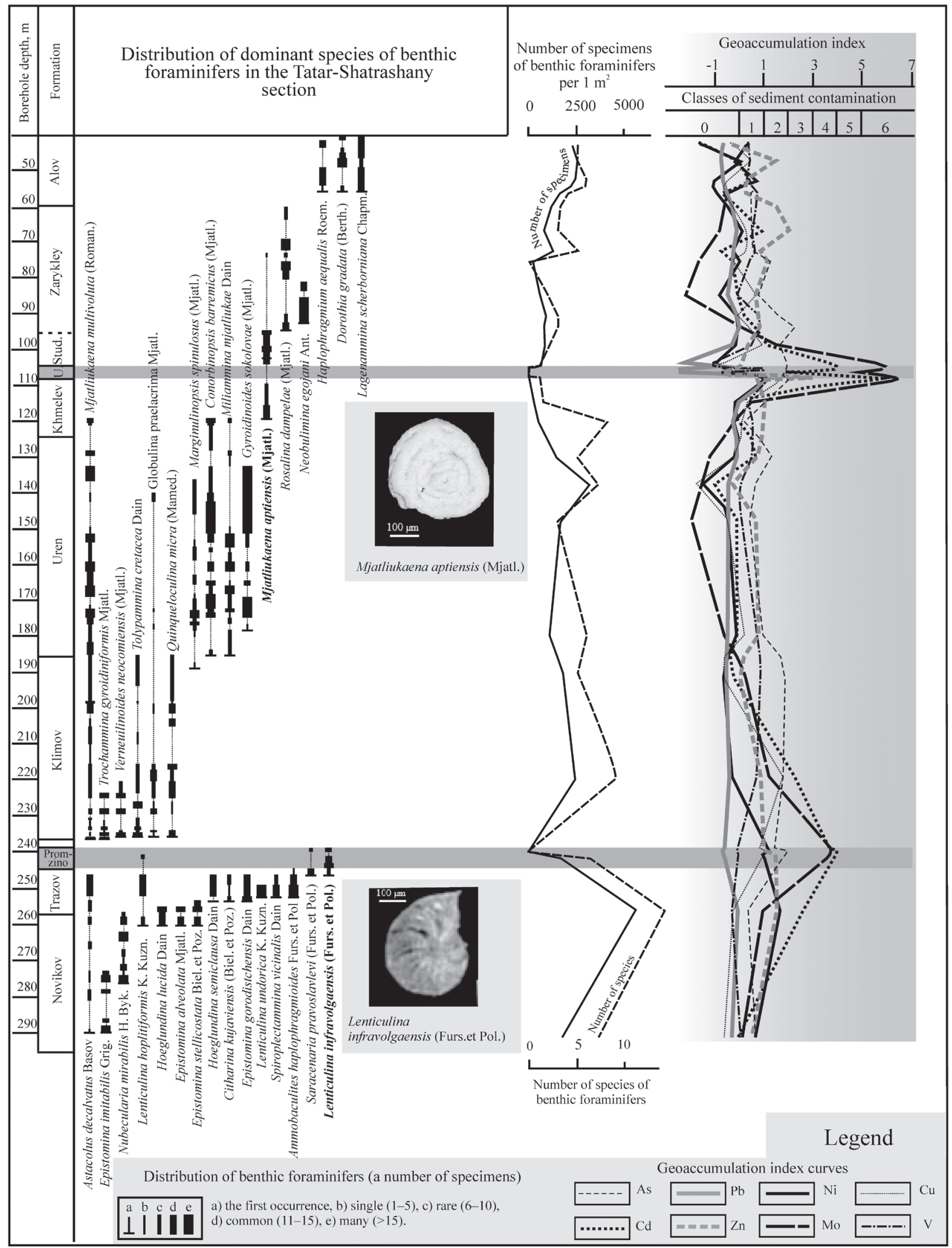

Figure 5. Distribution of dominant species of benthic foraminifers in the Upper Jurassic-Lower Cretaceous strata of the Tatar-Shatrashany borehole (modified from Zorina \& Startseva 2010), foraminiferal abundance and diversity curves, and the $\mathrm{I}_{\text {geo }}$ curves for toxic metals. 
Table 5. Index $\mathrm{I}_{\text {geo }}$ values for studied samples from the Tatar-Shatrashany section. Gray areas correspond to black shales.

\begin{tabular}{|c|c|c|c|c|c|c|c|c|c|}
\hline Sample & As & $\mathrm{Cd}$ & $\mathrm{Pb}$ & $\mathrm{Zn}$ & $\mathrm{Ni}$ & Mo & $\mathrm{Cu}$ & V & W \\
\hline $1 / 3$ & - & -1.58 & -0.65 & -0.24 & -1.57 & 0.44 & -0.30 & 0.37 & -0.80 \\
\hline $1 / 4$ & - & 0.08 & -0.65 & 1.51 & 0.10 & -0.12 & 0.51 & 0.44 & -0.86 \\
\hline $1 / 5$ & - & 0.38 & -0.72 & 0.16 & -1.03 & 0.69 & -0.55 & 0.36 & -0.78 \\
\hline $1 / 6$ & 0.56 & -0.67 & -0.45 & 1.01 & -0.84 & -0.46 & -0.57 & 0.77 & -0.80 \\
\hline $1 / 7$ & 0.53 & 0.92 & -0.10 & 2.13 & 0.17 & -0.72 & 0.27 & 0.57 & -0.73 \\
\hline $1 / 8$ & 0.53 & -0.74 & -0.22 & 0.85 & -0.25 & -1.28 & 0.28 & 0.66 & -0.70 \\
\hline $1 / 9$ & 1.28 & -0.17 & -0.20 & 1.21 & 0.06 & -1.66 & -0.19 & 0.43 & -0.90 \\
\hline $1 / 10$ & 0.76 & -0.04 & -0.53 & 0.67 & -0.82 & -2.22 & 0.70 & -0.05 & -1.01 \\
\hline $1 / 11$ & 1.46 & 0.18 & -0.01 & 0.78 & -0.10 & -0.76 & -0.02 & 0.85 & -0.68 \\
\hline $1 / 12$ & 2.28 & 0.68 & -0.10 & 0.86 & -0.04 & 0.15 & 0.36 & 0.85 & -0.86 \\
\hline $1 / 13$ & 1.70 & 1.32 & -0.13 & 0.36 & -0.15 & 1.79 & 0.93 & 0.35 & -0.64 \\
\hline $1 / 14$ & 1.92 & 3.92 & -2.30 & 0.08 & -0.93 & 5.91 & -0.80 & -1.08 & -2.99 \\
\hline $1 / 14 a$ & 1.85 & 3.98 & -0.50 & 0.08 & 0.77 & 5.96 & 0.85 & 1.09 & -1.41 \\
\hline $1 / 15$ & -0.04 & 1.78 & -2.53 & -0.52 & -0.88 & 5.01 & -0.66 & -0.85 & -2.80 \\
\hline $1 / 16$ & 1.79 & 4.20 & -0.40 & 0.26 & 0.93 & 6.08 & 1.00 & 1.07 & -1.10 \\
\hline $1 / 16 a$ & 1.94 & 6.02 & -0.37 & 3.18 & 0.95 & 6.01 & 0.89 & 0.86 & -1.20 \\
\hline $1 / 17$ & 2.01 & 5.31 & 1.15 & 0.78 & 1.03 & 6.48 & 1.69 & 1.18 & -0.55 \\
\hline $1 / 18$ & 1.16 & -0.28 & 0.11 & 1.08 & -0.08 & 0.53 & 0.37 & 0.46 & -0.48 \\
\hline $1 / 19$ & 0.20 & -0.06 & -0.23 & 0.98 & -0.21 & -0.09 & 0.14 & 0.54 & -0.70 \\
\hline $1 / 20$ & 1.34 & 0.73 & -0.07 & 0.82 & -0.07 & -1.09 & -0.11 & 0.50 & -0.85 \\
\hline $1 / 21$ & 0.71 & -0.99 & -0.42 & -0.24 & -1.43 & -1.83 & -1.72 & 0.10 & -1.71 \\
\hline $1 / 22$ & 0.42 & -0.09 & -0.40 & 0.68 & -0.43 & -1.96 & -0.45 & 0.12 & -0.77 \\
\hline $1 / 23$ & 0.99 & -0.06 & -0.40 & 0.77 & -0.09 & -0.67 & 0.23 & 0.81 & -0.62 \\
\hline $1 / 24$ & 1.86 & -0.32 & -0.54 & 0.07 & -0.55 & 0.21 & -0.70 & 0.88 & -0.52 \\
\hline $1 / 25$ & 1.60 & 2.22 & -0.45 & 0.67 & -0.25 & -1.51 & 0.26 & 0.47 & -0.81 \\
\hline $1 / 26$ & 1.48 & 3.73 & -0.52 & 1.02 & 1.18 & 3.77 & 0.81 & -0.04 & -1.93 \\
\hline $1 / 27$ & 2.00 & 4.03 & -0.69 & 1.48 & 0.96 & 3.87 & 1.13 & -0.03 & -1.99 \\
\hline $1 / 29$ & 0.38 & 2.62 & -0.07 & 1.60 & 1.70 & 0.95 & -0.24 & -0.27 & -1.20 \\
\hline $1 / 30$ & 0.66 & -0.08 & -0.29 & 0.50 & 0.64 & 0.12 & -0.60 & 0.12 & -0.40 \\
\hline
\end{tabular}

\section{Discussion}

\section{Trace elements as indicators of redox conditions}

As anoxic basins are widely thought to act as traps for stable sulphide-forming trace elements (e.g., Jacobs et al. 1985), specific elements must be located within the sediments rather than in the water column (Emerson \& Huested 1991). Several trace elements such as Mo, Cr, V,
$\mathrm{U}$, etc., are enriched in reducing sediments and are highly sensitive to redox changes, making them important proxies for paleo-redox reconstruction (Calvert \& Pedersen 1993, Jones \& Manning 1994, Crusius et al. 1996, Helz et al. 1996, Algeo \& Maynard 2004).

$\mathrm{U}$ is stable in form of insoluble $\mathrm{U}^{4+}$ under highly reducing conditions, which leads to the $U$ enrichment in sediments, whereas it exists as soluble $\mathrm{U}^{6+}$ under oxidizing conditions, leading to the $U$ release from sediments (Wignall \& Twitchett 1996, Guo et al. 2007). The U/Th 
Table 6. Quantitative data on abundance and diversity of benthic foraminifers from the Upper Jurassic-Lower Cretaceous rocks of the TatarShatrashany section.

\begin{tabular}{|c|c|c|c|c|c|}
\hline Samples & $\begin{array}{c}\text { Stage/ } \\
\text { Substage }\end{array}$ & Formation & $\begin{array}{l}\text { Number of specimens } \\
\text { per } 100 \mathrm{gr}\end{array}$ & $\begin{array}{c}\text { Number of specimens } \\
\text { per } 1 \mathrm{~m}^{2}\end{array}$ & $\begin{array}{l}\text { Number } \\
\text { of species }\end{array}$ \\
\hline $1 / 3$ & \multirow{4}{*}{ Mid Albian } & \multirow{4}{*}{ Alov } & 58 & 2320 & 5 \\
\hline $1 / 4$ & & & 63 & 2520 & 5 \\
\hline $1 / 5$ & & & 57 & 2280 & 6 \\
\hline $1 / 6$ & & & 37 & 1480 & 4 \\
\hline $1 / 7$ & \multirow{6}{*}{ Mid Aptian } & \multirow{6}{*}{ Zarykley } & 19 & 760 & 3 \\
\hline $1 / 8$ & & & 32 & 1280 & 5 \\
\hline $1 / 9$ & & & 0 & 0 & 0 \\
\hline $1 / 10$ & & & 16 & 640 & 2 \\
\hline $1 / 11$ & & & 24 & 960 & 3 \\
\hline $1 / 12$ & & & 19 & 760 & 3 \\
\hline $1 / 13$ & \multirow{9}{*}{ Lower Aptian } & Studenets & 21 & 840 & 2 \\
\hline $1 / 14$ & & \multirow{6}{*}{ Ulyanovsk } & 13 & 520 & 1 \\
\hline $1 / 14 \mathrm{a}$ & & & 0 & 0 & 0 \\
\hline $1 / 15$ & & & 0 & 0 & 0 \\
\hline $1 / 16$ & & & 0 & 0 & 0 \\
\hline $1 / 16 \mathrm{a}$ & & & 0 & 0 & 0 \\
\hline $1 / 17$ & & & 3 & 120 & 1 \\
\hline $1 / 18$ & & \multirow{2}{*}{ Khmelev } & 8 & 320 & 1 \\
\hline $1 / 19$ & & & 13 & 520 & 8 \\
\hline $1 / 20$ & \multirow{4}{*}{ Barremian } & \multirow{4}{*}{ Uren } & 35 & 1400 & 5 \\
\hline $1 / 21$ & & & 81 & 3240 & 7 \\
\hline $1 / 22$ & & & 44 & 1760 & 3 \\
\hline $1 / 23$ & & & 28 & 1120 & 6 \\
\hline $1 / 24$ & \multirow{2}{*}{ Uper Hauterivian } & \multirow{2}{*}{ Klimov } & 45 & 1800 & 5 \\
\hline $1 / 25$ & & & 61 & 2440 & 9 \\
\hline $1 / 26$ & \multirow{2}{*}{ Middle Volgian } & \multirow{2}{*}{ Promzino } & 0 & 0 & 0 \\
\hline $1 / 27$ & & & 35 & 1400 & 5 \\
\hline $1 / 29$ & Lower Volgian & Trazov & 142 & 5680 & 14 \\
\hline $1 / 30$ & Upper Kimmeridgian & Novikov & 41 & 1640 & 7 \\
\hline
\end{tabular}

ratio has also been used as an indicator of redox conditions due to the different behavior of $U$ and $T h$ in terms of solubility (Rimmer et al. 2004). In contrast to U, Th is known to be a highly reactive-particle element being practically associated with clay minerals, insoluble debris, or heavy metals (Anderson et al. 1983). A ratio of U/Th higher than 1.25 marks an anoxic environment, and $0.75-1.25$ signals a suboxic to dysoxic environment, while a ratio less than 0.75 indicates an oxic environment (Jones \& Manning 1994). In accordance with these assumptions, the Promzino and Ulyanovsk black shales are deposited in reducing environments of good preservation, while the host marls and mudrocks are deposited in the oxic conditions (Tab. 3, Fig. 3).

Wignall \& Myers (1988) proposed the authigenic uranium content as an index of bottom water anoxia in ancient sedimentary sequences. The $\mathrm{U}_{\mathrm{au}}$ content higher than 12.0 indicates anoxic conditions and 5.0-12.0 indicates suboxic to dysoxic conditions, while the $\mathrm{U}_{\mathrm{au}}$ content lower than 5.0 indicates oxic conditions (Jones \& Manning 
1994). Our results mark mostly oxic conditions in which the host mudrocks are deposited. The Promzino black shales are formed in strongly dysoxic conditions, while the Ulyanovsk bituminous strata are deposited in the mostly dysoxic to euxinic conditions (Tab. 3, Fig. 3).

As trace element concentrations of marine sediment represent mixtures of both detrital and authigenic components, it is only the concentrations of authigenic components that vary in response to redox changes in the water column (Jiang et al. 2007). In order to minimize the effects of weathering and post-depositional alteration, it is customary to normalize trace element concentrations to $\mathrm{Al}$ contents (Tribovillard et al. 2006). The Promzino and Ulyanovsk black shales show distinctly high V/Al, $\mathrm{U} / \mathrm{Al}$, and $\mathrm{Mo} / \mathrm{Al}$ ratios indicating reducing conditions, whereas organic carbon-poor strata show low values of these ratios marking oxic conditions in the basin (Tab. 3, Fig. 3).

Many researchers advocate the use of the TOC/P ratio as a robust proxy for productivity and bottom-water redox conditions (Tribovillard et al. 2006, Algeo \& Ingall 2007, Westermann et al. 2013). Increased levels of organic matter burial under anoxic bottom result in simultaneous remobilization and escape of phosphorus from sediment into the water. Studies of modern marine environments suggest that the TOC/P ratio of sediment that is deposited under permanently anoxic conditions is $>150$ whereas sediment that accumulated under oxic bottom-water conditions is characterized by TOC/P $<30$. Intermediate values indicate dysoxic conditions (Algeo \& Ingall 2007). Elevated TOC/P ratios in the organic carbonrich Promzino and Ulyanovsk Fms display that the strata were deposited under unstable oxic to anoxic conditions whereas the host mudrocks were formed mostly in oxicdysoxic conditions (Tab. 3, Fig. 3).

\section{Pyrite framboids as indicators of redox conditions}

Pyrite framboids are well known as raspberry-shaped, spherical aggregates $(2-50 \mu \mathrm{m}$ in diameter) consisting of cubo-octahedral to octahedral, equimorphic microcrystals $(0.5-2 \mu \mathrm{m})$ (Park et al. 2003, Cavalazzi et al. 2014). Pyrite framboids are very common in black shales being formed in weakly reducing euxinic conditions as synsedimentary precipitates due to bacterially driven iron- and sulfatereduction (Wignall et al. 2005, Oschmann 2011, Cavalazzi et al. 2014).

There is no agreement on the origin of pyrite framboids, probably because they could be formed under different environmental conditions. It has been assumed that magnetotactic bacteria could contain ferromagnetic sulphides (Taylor 1983, Sawlowicz 1993). Farina et al. (1990) showed that a colony of magnetotactic bacteria is similar to framboids in appearance and size $(5-10 \mu \mathrm{m})$.

As homogenization of framboids usually spreads from the centre to the surface of the spherules, organic matter and clay particles may be captured as inclusions (Sawlowicz 1993). The dense packing of the pyrite microgranules enveloping the organic matter in these framboids suggests a euxinic environment in the basin (Wang et al. 2012). Thus, it would be appropriate to assume euxinia in the basin, a condition in which hydrogen sulphide concentrations increase to toxic levels (Meyer \& Kump 2008). Close-packed framboids found in both Promzino and Ulyanovsk black shales (Fig. 4) point to the strong deficiency of oxygen in the study basin during the Late Jurassic and Early Aptian OAEs (Zorina et al. 2017). But, disintegrating framboids identified in Promzino black shales (Fig. 4) indicate partial or complete dissolution of the organic matter inside the framboids, which resulted in their decay. In conjunction with the abundant faunal remains, this likely indicates an increasing water oxygenation.

It has been established that abundant pyrite framboids can be found in areas of oxygen deficiency (dysoxic and anoxic conditions) and hydrogen sulphide contamination (euxinic conditions). In a basin with euxinia, due to the high density of framboids, their sizes remain uniformly small and do not vary over a wide range, whereas under conditions of insignificant oxidization, the diameters of framboids can differ markedly, while the standard deviation of their diameters is much larger than those formed under euxinic conditions (Bond \& Wignall 2010). Consequently, the dependence of the mean diameters of framboids on their standard deviation makes it possible to reveal the distribution of framboids over the indicated areas on the Bond-Wignall diagram and to determine redox conditions in the basin (Wilkin et al. 1996, Wilkin \& Barnes 1997, Wignall et al. 2010).

The mean diameter versus standard deviation plot indicates anoxic or dysoxic depositional environments for studied organic carbon-rich levels. So, the samples from the Lower Aptian OAE-1a-related black shales plot within the field of anoxic conditions, whereas, samples from the Middle Volgian black shales plot within the fields of both dysoxic and anoxic conditions (Fig. 4). This could evidence for mutative conditions under which minor oxidation alternated with periods of anoxia.

\section{Benthic foraminiferal response to toxic metal contamination}

Benthic foraminifers from recent basins have been successfully used as proxies for studying the impact of 
some pollutants, including heavy metals, chemicals, and oil, as well as thermal and organic contaminants. The development of test abnormalities is suitable for investigating the response of benthic foraminifers to stress including pollution (Yanko et al. 1999, Frontalini et al. 2009, Geslin et al. 1998). No malformations in the community of benthic foraminifers that could point to the toxicity of sediments were observed.

The response of benthic foraminifers to TM contamination in the sea basins of the geological past is poorly discussed in scientific reports, but it is well observed for recent basins. As assemblages of benthic foraminifers are known to be continuously exposed to variable concentrations of TM in seawater (Begum 2012), they suffer a declining diversity as a response to TM pollution (Debenay \& Fernandez 2009). The lowest foraminiferal diversity was found in the muddy sediments with high concentration of $\mathrm{Cu}, \mathrm{Zn}, \mathrm{Pb}, \mathrm{Cd}, \mathrm{Hg}, \mathrm{Cr}, \mathrm{Ni}, \mathrm{As}, \mathrm{Rb}$, $\mathrm{Br}$, and some others (Alve 1991, Alyazichi et al. 2014, Murray 2006, Caruso et al. 2011).

The calculated parameters of abundance and diversity of benthic foraminifers in the study section are generally correlated with each other, and their variation shows that the communities of benthic foraminifers were numerous and diverse in the Late Jurassic-Early Cretaceous, except for the Late Jurassic and Early Cretaceous anoxic episodes (Fig. 5).

As buried foraminiferal assemblages represent the product of both subtle environmental changes and postdepositional modifications (Olszewski 2004, Berkeley 2009), low foraminiferal abundance and diversity could be caused by postpositional taphonomic effects. The effect of dissolution of foraminifers is well-known (Murray 1989, Murray \& Alve 1999). Assemblages may experience compositional changes due to selective taphonomic loss during burial. Berkeley (2009) assumed that it could be caused by relative sea-level changes. Although this approach explains well recurring selective taphonomic losses in foraminiferal assemblages observed in the geological past, it can be applied mostly to modern sediments accumulating in narrowly constrained zones at specific positions relative to the tide (Berkeley 2009). Thus, the observed decrease in foraminiferal abundance and diversity was probably not caused by the aforementioned post-depositional taphonomic effects but more likely by anoxic conditions and in particular, by TM contamination of sediments in which the foraminifers are buried.

In the Promzino black shales, five species of benthic foraminifers, including the zonal species Lenticulina infravolgaensis (Furs. et Pol.) are found only in few samples (Fig. 5). In most of Promzino sediment samples, the $\mathrm{I}_{\text {geo }}$ index indicates significant contamination by $\mathrm{Cd}$ and Mo.
On the contrary, benthic foraminifers are not found, and only a few specimens of the species Mjatliukaena aptiensis (Mjatl.) are identified at the lower and upper layers of the Ulyanovsk black shales (Fig. 5). At the same time, the concentrations of $\mathrm{Cd}$ and Mo in rocks are extremely high, and according to the index $\mathrm{I}_{\text {geo }}$ values, the sediments could be classified as extremely contaminated by Mo and moderately to extremely contaminated by $\mathrm{Cd}$.

The effects of metal toxicity are known for some extant nannoplankton species. For example, cadmium inhibits calcification and copper is not tolerated by several coccolithophorid species (Brand 1994). In the Cretaceous, Biscutum suffered the presence of toxic metals introduced in large quantities via hydrothermal plumes (Erba 2004). Similar enrichment in Mo and some other toxic elements are reported to be observed in Lower Cambrian black shales in southern China (Poňavič et al. 2006).

To sum up, the integrated data provide an evidence for mostly dysoxic conditions in the North-Eastern Peri Tethys during the Late Jurassic anoxic event, during which the habitat conditions were not destructive for benthic foraminifers. The most toxic-resistant species was Lenticulina infravolgaensis (Furs. et Pol.).

Strong anoxia in Early Aptian OAE 1a that contributed to the extremely contaminated sediments is considered to have been fatal for benthic foraminifers. The most toxic-resistant species was the zonal species Mjatliukaena aptiensis (Mjatl.).

\section{Modeling paleoenvironments in the North-Eastern Peri-Tethys in Early Aptian}

Since OAEs are interpreted as a concatenation of sedimentary, geochemical, and biological events (Jenkyns 2010), the Late Jurassic and the Early Aptian OAEs may cause and record massive climate, sea-level, and environmental changes in the epeiric basin of the North-Eastern Peri-Tethys. The most dramatic changes in depositional environments are found to take place during the Early Aptian OAE-1a which is shown in the paleoenvironmental models presented (Fig. 6). The latest Barremian-earliest Aptian (pre-event) conditions were favorable for nektonic inhabitants such as ammonites and belemnites due to normal oxygen circulation and seawater temperatures ranging between 7 and $18{ }^{\circ} \mathrm{C}$ (Zakharov et al. 2013) (Fig. 6A). During this period, the bioturbated dark gray mudrocks with a significant contribution of terrigenous mud, silt, and pyroclastic material accumulated at an estimated depth of around $200 \mathrm{~m}$ (Zorina 2009, 2014, 2019; Zorina et al. 2020). Element geochemistry of the mudrocks confirms uncontaminated oxic conditions (Figs 3,5 ), which were suitable for benthic foraminifers and the activity of burrowing organisms. 
Accompanied by global warming and eustatic highstand (Haq 2014) the OAE 1a has been manifested in the studied region by a rise in a seafloor temperature to

\section{A}

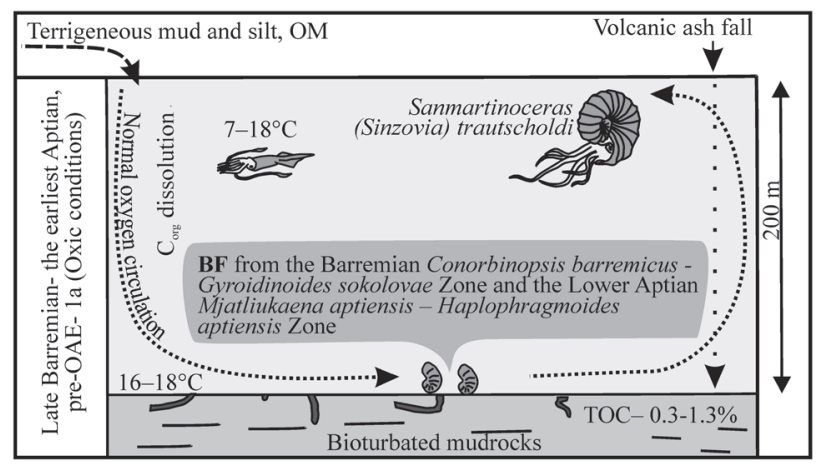

B

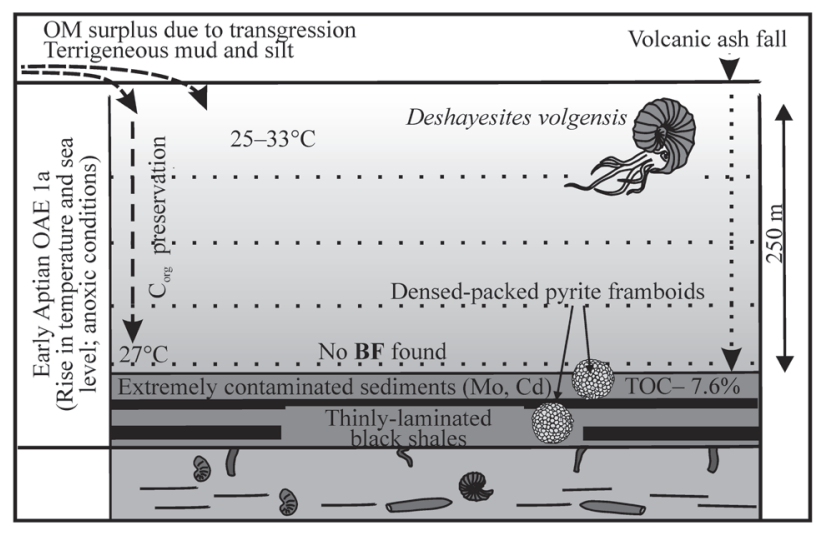

C
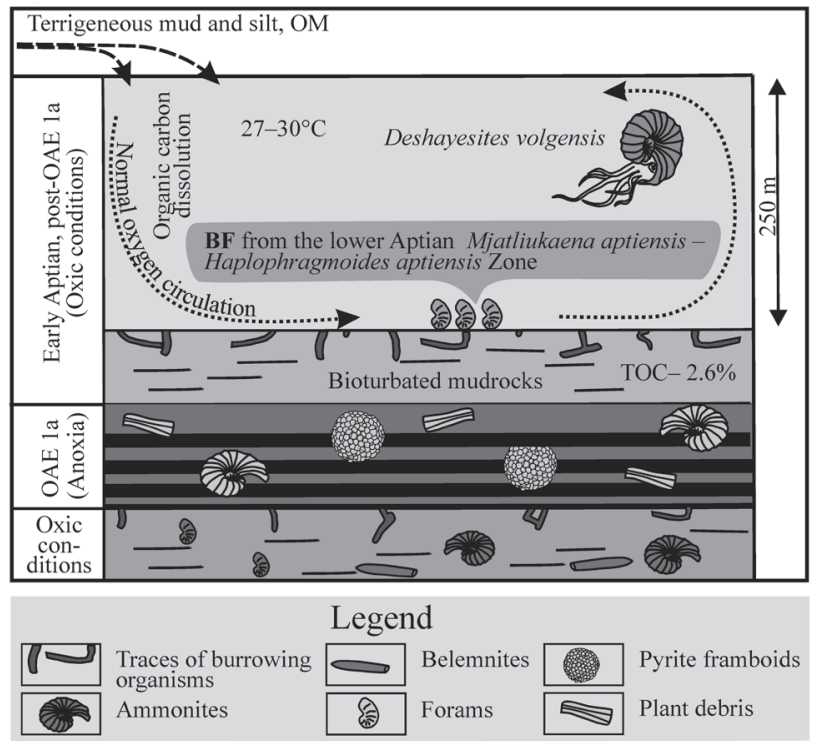

Figure 6. Models to illustrate the variety of biotic and abiotic processes characteristic of the pre-OAE 1a (A), OAE 1a (B), post-OAE 1a (C) in the North-Eastern Peri-Tethys. Temperature is given after (Zakharov et al. 2013). Abbreviations: $\mathrm{BF}-$ benthic foraminifers; $\mathrm{OM}$ - organic matter. For Lithology, see Legend in Fig. 2. $25-33^{\circ} \mathrm{C}$ (Zakharov et al. 2013), the $3^{\text {rd }}$ order transgression (Zorina 2016), and basin depth increase to $250 \mathrm{~m}$ (Zorina 2014, 2019) (Fig. 6 b). Normal oxygenated water circulation was changed by "sluggish" water stagnation which has led to the deposition of laminated strata, organic matter burial, formation of close-packed pyrite framboids, and a spread of anoxia in the bottom part of the basin (Fig. 6B). The latest is evidenced by the elevated values of redox-sensitive elements and their ratios, and pyrite framboids diameter measurements (Figs 3-5). The Lower Aptian black shales showed extreme contamination by $\mathrm{Mo}$ and $\mathrm{Cd}$, thus the anoxic environment became unsuitable for the life of benthic foraminifers due to the combined effects of oxygen deficiency, possible excess of free hydrogen sulphide, and elevated concentrations of toxic metals.

The post-OAE 1a conditions are proposed to record a recovery phase during which normal water circulation was recovered (Fig. 6C). During this phase, the seawater temperatures varied between 27 and $30^{\circ} \mathrm{C}$ (Zakharov et al. 2013), water depth was estimated to be at about $250 \mathrm{~m}$ (Zorina 2014, 2019), and bioturbated uncontaminated dark gray mudrocks with TOC value of $2.6 \%$ accumulated. The toxic and disastrous consequences of the OAE 1a anoxia terminated and more suitable conditions for benthic foraminifers from the Lower Aptian Mjatliukaena aptiensis-Haplophragmoides aptiensis Zone were restored directly above the black shales, including the only toxic-resistant species Mjatliukaena aptiensis (Mjatl.) (Fig. 5).

\section{Conclusions}

Reducing conditions are identified and toxic environments reconstructed during the OAE $1 \mathrm{a}$ in the deepening and transgressing epeiric basin in the North-Eastern PeriTethys.

Extreme contamination of the OAE 1a-related black shales by Mo and Cd in conjunction with the absence of oxygen could result in conditions not suitable for benthic foraminifers dwelling. The key species Mjatliukaena aptiensis (Mjatl.) is regarded to be one of the toxic-resistant species that successfully recovered from the OAE 1a anoxic stress.

Comparing to the Late Jurassic OAE, the integrated data indicate moderately contaminated black shales and mainly dysoxic conditions under which habitat conditions were not completely detrimental for benthic foraminifers. The most toxic-resistant species was Lenticulina infravolgaensis (Furs. et Pol.).

The paleoenvironment models integrated biotic and abiotic data may help to better understand modern climate changes. 


\section{Acknowledgments}

The author thanks Tomáš Kumpan, Ondřej Bábek, and the anonymous reviewer for their critical comments and useful suggestions to improve the manuscript. N.V. Sokerina and B.I. Gareev are acknowledged for their help with providing analyses. This work was supported by the Ministry of Science and Higher Education of the Russian Federation under agreement No. 075-15-2020-931 within the framework of the development program for a world-class Research Center "Efficient development of the global liquid hydrocarbon reserves".

\section{References}

Algeo, T.J. \& Ingall, E. 2007. Sedimentary $\mathrm{C}_{\text {org }}$ : P ratios, paleocean ventilation, and Phanerozoic atmospheric $\mathrm{pO}_{2}$. Palaeogeography, Palaeoclimatology, Palaeoecology 256, 130-155. DOI 10.1016/j.palaeo.2007.02.029

Algeo, T.J. \& Maynard, J.B. 2004. Trace-element behavior and redox facies in core shales of Upper Pennsylvanian Kansastype cyclothems. Chemical Geology 206, 289-318.

DOI 10.1016/j.chemgeo.2003.12.009

ALvE, E. 1991. Benthic foraminifera in sediment cores reflecting heavy metal pollution in Sorfjord, western Norway. Journal of Foraminiferal Research 21(1), 1-19.

DOI 10.2113/gsjfr.21.1.1

Alyazichi, Y.M., Jones, B. \& McLean, E. 2014. Environmental assessment of benthic foraminiferal and pollution in Gunnamatta Bay, NSW, Australia, 2495-2504. In Shimizu, N., Kaneko, K. \& Kodama, J. (eds) Rock Mechanics for Global Issues - Natural Disasters, Environment, and Energy. Proceedings of the 2014 ISRM International Symposium.

Anderson, R.F., Bacon, M.P. \& Brewer, P.G. 1983. Removal of ${ }^{230} \mathrm{Th}$ and ${ }^{231} \mathrm{~Pa}$ at ocean margins. Earth and Planetary Science Letters 66, 73-90. DOI 10.1016/0012-821X(83)90127-9

AtKinson, W.J. 1967. Regional geochemical studies in county Limerick, Ireland with particular reference to selenium and molybdenum. 337 pp. Ph.D. thesis, Imperial College, London.

Begum, G. (ed.) 2012. Ecotoxicology. 146 pp. InTech, Croatia. DOI $10.5772 / 1185$

Berkeley, A. 2009. Understanding the role of taphonomy and post-depositional processes on the intertidal stratigraphic record. Palaios 24, 271-272.

DOI 10.2110/palo.2009.S03

Bond, D.P.G. \& Wignall, P.B. 2010. Pyrite framboid study of marine Permian-Triassic boundary sections: A complex anoxic event and its relationship to contemporaneous mass extinction. GSA Bulletin 122(7/8), 1265-1279.

DOI 10.1130/B30042.1

Bottini, C., Erba, E., Tiraboschi, D., Jenkyns, H.C., Schouten, S. \& Sinninghe Damsté, J.S. 2015. Climate variability and ocean fertility during the Aptian Stage. Climate Past 11, 383-402. DOI 10.5194/cp-11-383-2015

Brand, L.E. 1994. Physiological ecology of marine coccolithophores, 39-49. In Winter, A. \& Siesser, W.G. (eds) Coccolithophores. Cambridge University Press, Cambridge.
Cavalazzi, B., Agangi, A., Barbieri, R., Franchi, F. \& Gasparotтo, G. 2014. The Formation of Low-Temperature Sedimentary Pyrite and Its Relationship with BiologicallyInduced Processes. Geology of Oil Deposits 56, 395-408. DOI 10.1134/S107570151405002X

Calvert, S.E. \& Pedersen, T.F. 1993. Geochemistry of recent oxic and anoxic marine sediments: implications for the geological record. Marine Geology 113, 67-88. DOI 10.1016/0025-3227(93)90150-T

Caruso, A., Cosentino, C. Tranchina, L. \& Brai, M. 2011. Response of benthic foraminifera to heavy metal contamination in marine sediments (Sicilian coasts, Mediterranean Sea). Chemistry and Ecology 27(1), 9-30. DOI 10.1080/02757540.2010.529076

Crusius, J., Calvert, S., Pedersen, T. \& Sage, D. 1996. Rhenium and molybdenum enrichments in sediments as indicators of oxic, suboxic, and sulfidic conditions of deposition. Earth and Planetary Science Letters 145, 65-78. DOI 10.1016/S0012-821X(96)00204-X

Dean, W.E., Gardner, J.V. \& Piper, D.Z. 1997. Inorganic geochemical indicators of glacial-interglacial changes in productivity and anoxia on the California continental margin. Geochimica et Cosmochimica Acta 61, 4507-4518. DOI 10.1016/S0016-7037(97)00237-8

Debenay, J.-P. \& Fernandez, J.-M. 2009. Benthic foraminifera records of complex anthropogenic environmental changes combined with geochemical data in a tropical bay of New Caledonia (SW Pacific). Marine Pollution Bulletin 59, 311-322. DOI 10.1016/j.marpolbul.2009.09.014

Emerson, S.R. \& Huested, S.S. 1991. Ocean anoxia and the concentrations of molybdenum and vanadium in seawater. Marine Chemistry 34, 177-196. DOI 10.1016/0304-4203(91)90002-E

ErbA, E. 2004. Calcareous nannofossils and Mesozoic oceanic anoxic events. Marine Micropaleontology 52, 85-106. DOI 10.1016/j.marmicro.2004.04.007

Erba, E., Bottini, C., Weissert, J.H. \& Keller, C.E., 2010. Calcareous Nannoplankton Response to Surface-Water Acidification Around Oceanic Anoxic Event 1a. Science 329, 428-432. DOI 10.1126/science. 1188886

Farina, F., Esquivel, D.M.S \& Lins de Barros H.G.P. 1990. Magnetic iron-sulphur crystals from a magnetotactic microorganism. Nature 343, 256-258.

DOI $10.1038 / 343256 \mathrm{a} 0$

French, K.L., Sepúlveda, J., Trabucho-Alexandre, J., Gröcke, D.R. \& Summons, R.E. 2014. Organic geochemistry of the early Toarcian oceanic anoxic event in Hawsker Bottoms, Yorkshire, England. Earth and Planetary Science Letters 390, 116-127. DOI 10.1016/j.eps1.2013.12.033

Friedrich, O. 2010. Benthic foraminifera and their role to decipher paleoenvironment during mid-Cretaceous Oceanic Anoxic Events - the "anoxic benthic foraminifera" paradox. Revue de micropaléontologie 53, 175-192.

DOI 10.1016/j.revmic.2009.06.001

Frontalini, F., Buosi, C., Da Pelo, S., Coccioni, R., Cherchi, A. \& BuccI., C. 2009. Benthic Foraminifera as Bio-Indicators of Trace Element Pollution in the Heavily Contaminated Santa 
Gilla Lagoon (Cagliari, Italy). Marine Pollution Bulletin 58(6), 858-877. DOI 10.1016/j.marpolbul.2009.01.015

Galiakberov, A., Zorina S., Maksyutova, L., DzhalmukhaNOVA, R., Zaripova, G. \& NikAshin, K. 2018. Toxicity of high-carbon sediments: case Study from anoxic basins of the East European and West Siberian Platforms, 340-343. In Nourgaliev, D.K. (ed.) Advances in Devonian, Carboniferous, and Permian Research: Stratigraphy, Environments, Climate, and Resources. Filodiritto Editore-Proceedings.

Gavrilov, Yu.O., Shchepetova, E.V., Baraboshkin, E.Yu. \& Shcherbinina, E.A. 2002. The Early Cretaceous anoxic basin of the Russian Plate: sedimentology and geochemistry. Lithology and Mineral Resources 37, 310-329.

DOI 10.1023/A:1019943305677

Geslin, E., Debenay, J.P. \& Lesourd, M. 1998. Abnormal wall textures and test deformation in Ammonia (Hyaline Foraminifer). Journal of Foraminiferal Research 28(2), 148-156.

Guo, Q., Shields, G.A., Liu, C., Strauss, H., Zhu, M., Pi, D., Goldberg, T. \& YAnG, X. 2007. Trace element chemostratigraphy of two Ediacaran-Cambrian successions in South China: implications for organosedimentary metal enrichment and silicification in the Early Cambrian. Palaeogeography, Palaeoclimatology, Palaeoecology 254, 194-216. DOI 10.1016/j.palaeo.2007.03.016

Haq, B.U. 2014. Cretaceous eustasy revisited. Global and Planetary Change 113, 44-58.

DOI 10.1016/j.gloplacha.2013.12.007

Helz, G.R., Miller, C.V., Charnock, J.M., Mosselmans, J.F.M., Pattrick, R.A.D., Garner, C.D. \& Vaughan, D.J. 1996. Mechanisms of molybdenum removal from the sea and its concentration in black shales: EXAFS evidence. Geochimica et Cosmochimica Acta 60, 3631-3642.

DOI 10.1016/0016-7037(96)00195-0

JACOBS, L., Emerson, S. \& SKeI, J. 1985. Partitioning and transport of metals across the $\mathrm{O} 2 / \mathrm{H} 2 \mathrm{~S}$ interface in a permanently anoxic basin: Framvaren Fjord, Norway. Geochimica et Cosmochimica Acta 49, 1433- 1444. DOI 10.1016/0016-7037(85)90293-5

Jahren, A.H., Arens, N.C., Sarmiento, G., Guerrero, J. \& Amundson, R. 2001. Terrestrial record of methane hydrate dissociation in the Early Cretaceous. Geology 29, 159-162. DOI10.1130/0091-7613(2001)029<0159:TROMHD >2.0.CO;2

JenKyns, H.C. 2010. Geochemistry of oceanic anoxic events. Geochemistry. Geophysics. Geosystems 11(3), Q03004. DOI 10.1029/2009GC002788

Jiang, S.Y., ZhaO, H.X., Chen, Y.Q., Yang, T., YanG, J.H. \& LING, H.F. 2007. Trace and rare earth element geochemistry of phosphate nodules from the lower Cambrian black shale sequence in the Mufu Mountain of Nanjing, Jiangsu province, China. Chemical Geology 244(3-4), 584-604.

DOI 10.1016/j.chemgeo.2007.07.010

Jones, B. \& MANNING, D.A.C. 1994. Comparison of geochemical indices used for the interpretation of palaeoredox conditions in ancient mudstones. Chemical Geology 111, 111-129. DOI 10.1016/0009-2541(94)90085-X

Keller, C.E., Hochuli, P.A., Weissert, H., Bernasconi, S.M., Giorgioni, M. \& Garcia, T.I. 2011. A volcanically induced climate warming and floral change preceded the onset of OAE1a (Early Cretaceous). Palaeogeography, Palaeoclimatology, Palaeoecology 305, 43-49.

DOI 10.1016/j.palaeo.2011.02.011

Ketris, M.P. \& Yudovich, Y.E. 2009. Estimation of clarkes for carbonaceous biolithes: world averages for trace elements contents in black shales and coals. International Journal of Coal Geology 78, 135-148. DOI 10.1016/j.coal.2009.01.002

Larson, R.L. \& Erba, E. 1999. Onset of the mid-Cretaceous greenhouse in the Barremian-Aptian: igneous events and the biological, sedimentary, and geochemical responses. Paleoceanography 14, 553-678.

DOI 10.1029/1999PA900040

Lee, J.-S., Chon, H.-T., Kim, J.-Sh., Kim, K.-W. \& Moon, H.-S. 1998. Enrichment of potentially toxic elements in areas underlain by black shales and slates in Korea. Environmental Geochemistry and Health 20, 135-147.

Li, Y.X., Bralower, T.J., Montanez, I.P., Osleger, D.A., Arthur, M.A., Bice, D.M., Herbert, T.D., Erba, E. \& Premoli SiLVA, I. 2008. Toward an orbital chronology for the early Aptian Oceanic Anoxic Event (OAE1a, 120 Ma). Earth and Planetary Science Letters 271, 88-100.

DOI 10.1016/j.eps1.2008.03.055

Lund, L.J., Betty, E.E., Page, A.L. \& Elliott, R.A. 1981. Occurrence of naturally high cadimium levels in soils and its accumulation by vegetation. Journal of Environmental Quality 10, 551-556.

DOI 10.2134/jeq1981.00472425001000040027x

Maksyutova, L.F., Galiakberov, A.I., Dzhalmukhanova, R.I., Zaripova, G.M., NiKashin, K.I. \& Zorina, S.O. 2018. New data on greenhouse-gas footprint from black shales of Russian and West Siberian Platforms, Russia, 375-380. In Nourgaliev, D.K. (ed.) Advances in Devonian, Carboniferous, and Permian Research: Stratigraphy, Environments, Climate, and Resources. Filodiritto Editore-Proceedings.

Malinverno, A., Erba, E. \& Herbert, T.D. 2010. Orbital tuning as an inverse problem: Chronology of the early Aptian oceanic anoxic event 1a (Selli Level) in the Cismon APTICORE. Paleoceanography 25, PA2203. DOI 10.1029/2009PA001769

Menegatti, A.P., Weissert, H., Brown, R.S., Tyson, R.V., Farrimond, P., Strasser, A. \& Caron, M. 1998. Highresolution $\delta^{13} \mathrm{C}$ stratigraphy through the early Aptian "Livello selli" of the Alpine tethys. Paleoceanography 13, 530-545. DOI 10.1029/98PA01793

Meyer, K.M. \& Kump, L.R. 2008. Oceanic Euxinia in Earth History: Causes and Consequences. Annual Review of Earth and Planetary Sciences 36, 251-288.

DOI 10.1146/annurev.earth.36.031207.124256

Moosavizadeh, M.A., Mahboubi, A., Moussavi-Harami, R.M.A. \& Kavoosi, M.A., 2014. Early Aptian Oceanic Anoxic Event (OAE 1a) in moderately Arabian Plate Setting: An Example from Dariyan Formation in Zagros Fold-Trust Belt, SE Iran. Arabian Journal of Geosciences 7, 4745-4756. DOI 10.1007/s12517-013-1025-Z

MülleR, G. 1969. Index of geo-accumulation in Sediments of the Rhine River. Geojournal 2, 108-118. 
Murray, J.W. 1989. Syndepositional dissolution of calcareous foraminifera in moder shallow-water sediments. Marine Micropaleontology 15, 117-121.

DOI /10.1016/0377-8398(89)90007-8

Murray, J.W. 2006. Ecology and Applications of Benthic Foraminifera. 400 pp. Cambridge University Press, New York. DOI 10.1017/CBO9780511535529

Murray, J.W. \& Alve, E. 1999. Natural dissolution of modern shallow water benthic foraminifera: Taphonomic effects on the palaeoecological record. Palaeoecology, Palaeogeography, Palaeoclimatology 146, 195-209.

Nozaki, T., Kato, Ya. \& SuzuKi, K. 2013. Late Jurassic ocean anoxic event: evidence from voluminous sulfide deposition and preservation in the Panthalassa. Scientific Reports 3(1889), 1-6.

Olferiev, A.G., Beniamovski, V.N., Vishnevskaya, V.S., Ivanov, A.V., Kopaevich, L.F., Ovechina, M.N., Pervushov, E.M., Sel'tser, V.B., Tesakova, E.M., Kharitonov, V.M. \& Shcherbinina, E.A. 2008. Upper Cretaceous deposits in the northwest of Saratov Region, Part 2: Problems of chronostratigraphy and regional geological history. Stratigraphy and Geological Correlation 16, 267-294.

DOI 10.1134/S0869593808030040

OLsZEwSKI, T.D. 2004. Modeling the influence of taphonomic destruction, reworking, and burial on time-averaging in fossil accumulations. Palaios 19, 39-50.

DOI10.1669/0883-1351(2004)019<0039:MTIOTD>2.0.CO;2

Oschmann, W. 2011. Black shales, 201-210. Reitner, J. \& Thiel, V. (eds) Encyclopedia of Geobiology. Dordrecht, Springer Science+Business Media B.V. DOI 10.1007/978-1-4020-9212-1 37

PARK, M.-H., KIM, I.-S. \& RYU, B.-J. 2003. Framboidal pyrites in late Quaternary core sediments of the East Sea and their paleoenvironmental implications. Geosciences Journal 7(3), 209-215. DOI 10.1007/BF02910287

Percival, L.M.E., Tedeschi, L.R., Creaser, R.A., Bottini, C., Erba, E., Giraud, F., Svensen, H., Savian, J., Trindade, R., Coccioni, R., Frontalini, F., Jovane, L., Mather, T.A. \& Jenkyns, H.C. 2021. Determining the style and provenance of magmatic activity during the Early Aptian Oceanic Anoxic Event (OAE 1a). Global and Planetary Change 200, 103461. DOI 10.1016/j.gloplacha.2021.103461

Poňavič, M., Pašava, L., Vymazalová, A., Kř́íbek, B., Deng, H., Luo, T., Li, C. \& ZenG, M. 2006. Fractionation of toxic trace elements in soils around Mo-Ni black shale-hosted mines, Zunyi region, southern China: Environmental implications. Bulletin of Geosciences 81, 197-206.

DOI 10.3140/bull.geosci.2006.03.197

Premoli Silva, I., Erba, E., Salvini, G., Locatelli, C. \& Verga, D. 1999. Biotic changes in Cretaceous oceanic anoxic events of the Tethys. Journal of Foraminiferal Research 29, 352-370.

Rimmer, S.M., Thompson, J.A., Goodnight, S.A. \& Robl, T.L. 2004. Multiple controls on the preservation of organic matter in Devonian-Mississippian marine black shales: geochemical and petrographic evidence. Palaeogeography, Palaeoclimatology, Palaeoecology 215, 125-154.

DOI 10.1016/S0031-0182(04)00466-3
Rudnick, R.L. \& GaO, S. 2003. Composition of the Continental Crust. Treatise on Geochemistry 3, 1-64. Elsevier, Amsterdam. DOI 10.1016/B0-08-043751-6/03016-4

SAwlowicz, Z. 1993. Pyrite framboids and their development: a new conceptual mechanism. Geologische Rundschau 82, 148-156. DOI 10.1007/BF00563277

Scotese, C.R. 2014. The PALEOMAP Project PaleoAtlas for ArcGIS, version 2, Vol. 2, Cretaceous Plate Tectonic, Paleogeographic, and Paleoclimatic Reconstructions. Maps 16-32. PALEOMAP Project, Evanston, IL.

Scotese, C.R. 2016. Some Thoughts on Global Climate Change: The transition from Icehouse to Hothouse, in the Earth History: The evolution of the Earth System. PALEOMAP Project, Evanston, IL.

Schlanger, S.O. \& Jenkyns, H.C. 1976. Cretaceous oceanic anoxic events: causes and consequences. Geologieen Mijnbouw 55, 179-184.

TAYLOR, G.R. 1983. A mechanism for framboid formation - The role of bacteria. Mineralium Deposita 18, 129-130. DOI 10.1007/BF00206701

Tejada, M.L.G., Suzuki, K., Kuroda, J., Coccioni, R., Mahoney, J.J. Ohкоuchi, N., Sakamoto, T. \& Tatsumi, Y. 2009. Ontong Java Plateau eruption as a trigger for the early Aptian oceanic anoxic event. Geology 37, 855-858.

DOI 10.1130/G25763A.1

Trabucho-Alexandre, J., Hay, W.W. \& de Boer, P.L. 2012. Phanerozoic environments of black shale deposition and the Wilson Cycle. Solid Earth 3, 29-42. DOI 10.5194/se-3-29-2012

Tribovillard, N., Algeo, T.J., Lyons, T. \& Riboulleau, A. 2006. Trace-metals as paleoredox and paleoproductivity proxies: an update. Chemical Geology 232, 12-32. DOI 10.1016/j.chemgeo.2006.02.012

Ulmishek, G. 2003. Petroleum geology and resources of the West Siberian basin, Russia. U.S.G.S. Bulletin 2201-G, 49.

Van Breugel, Y., Schouten, S., Tsikos, H., Erba, E., Price, G.D. \& Sinninghe Damsté, J.S. 2007. Synchronous negative carbon isotope shifts in marine and terrestrial biomarkers at the onset of the early Aptian oceanic anoxic event 1a: Evidence for the release of $13 \mathrm{C}$-depleted carbon into the atmosphere. Paleoceanography 22(1), PA1210. DOI 10.1029/2006PA001341

VINE, J.D. \& Tourtelot, E.B. 1970. Geochemistry of black shale deposit \pm a summary report. Economic Geology 65, 253-272. DOI 10.2113/gsecongeo.65.3.253

Von Bargen, D. \& Lehmann, J. 2014. Benthic ecosystem response to the deposition of lower Aptian black shales in an epicontinental sea. Cretaceous Research 51, 208-224. DOI 10.1016/j.cretres.2014.06.006

VodyanitskiI, Yu.N. 2012, Standards for the contents of heavy metals and metalloids in soils. Eurasian Soil Science 45, 321-328. DOI 10.1134/S1064229312030131

WANG, L., ShI, X. \& JiAng G. 2012. Pyrite morphology and redox fluctuations recorded in the Ediacaran Doushantuo Formation. Palaeogeography, Palaeoclimatology, Palaeoecology 333, 218-227. DOI 10.1016/j.palaeo.2012.03.033

Westermann, S., Stein, M., Matera, V., Fiet, N., Fleitmann, D., 
Adatte, T. \& Föllmi, K.B. 2013. Rapid changes in the redox conditions of the western Tethys Ocean during the early Aptian oceanic anoxic event. Geochimica et Cosmochimica Acta 121, 467-486. DOI 10.1016/j.gca.2013.07.023

WignALL, P.B. \& Myers, K.J. 1988. Interpreting the benthic oxygen levels in mudrocks: a new approach. Geology 16, 452-455. DOI 10.1130/0091-7613(1988)016<0452:IBOLIM >2.3.CO;2

Wignall, P.B. \& Twitchett, R.J. 1996. Oceanic anoxia and the end Permian mass extinction. Science 272, 1155-1158.

DOI 10.1126/science.272.5265.1155

Wignall, P.B., Newton, R. \& Brookfield, M.E. 2005. Pyrite framboid evidence for oxygenpoor deposition during the Permian-Triassic crisis in Kashmir. Palaeogeography, Palaeoclimatology, Palaeoecology 216, 183-188. DOI 10.1016/j.palaeo.2004.10.009

Wignall, P.B., Bond, D.P.G., Kuwahara, K., Kakuwa, Y., Newton, R.J. \& Poulton, S.W. 2010. An 80 million year oceanic redox history from Permian to Jurassic pelagic sediments of the Mino-Tamba terrane, SW Japan, and the origin of four mass extinctions. Global and Planetary Change 71, 109-123. DOI 10.1016/j.gloplacha.2010.01.022

Wilkin, R.T. \& BARnes, H.L. 1997. Formation processes of framboidal pyrite. Geochimica et Cosmochimica Acta 61(2), 323-339. DOI 10.1016/S0016-7037(96)00320-1

Wilkin, R.T., Barnes, H.L. \& Brantley, S.L. 1996. The size distribution of framboidal pyrite in modern sediments: An indicator of redox conditions. Geochimica et Cosmochimica Acta 60, 3897-3912. DOI 10.1016/0016-7037(96)00209-8

Yanko, V., Arnold, A.J. \& Parker, W.C. 1999. Effects of Marine Pollution on Benthic Foraminifera, 217-235. SEN Gupta, B.K (ed.) Modern Foraminifera. Kluwer Academic Publisher, Dordrecht. DOI 10.1007/0-306-48104-9_13

Zakharov, Yu.D., Baraboshin, E.Yu., Weissert, H., Michailova, I.A., Smyshlyaeva, O.P. \& Safronov, P.P. 2013, Late Barremian-early Aptian climate of the northern middle latitudes: Stable isotope evidence from bivalve and cephalopod mollusks of the Russian Platform. Cretaceous Research 44, 183-201. DOI 10.1016/j.cretres.2013.04.007
Zorina, S.O. 2007. Stratigraphy of middle-upper Jurassic deposits in the East Russian plate. Stratigraphy and Geological Correlation 15, 267-276. DOI 10.1134/S0869593807030033

Zorina, S.O. 2009. Sequence stratigraphy of Lower Cretaceous deposit on the eastern Russian Plate. Russian Geology and Geophysics 50, 430-437. DOI 10.1016/j.rgg.2008.08.007

ZorinA, S.O. 2014. Eustatic, tectonic, and climatic signatures in the Lower Cretaceous siliciclastic succession on the Eastern Russian Platform. Palaeogeography, Palaeoclimatology, Palaeoecology 412, 91-98.

DOI 10.1016/j.palaeo.2014.07.029

ZorinA, S.O. 2016. Sea-level and climatic controls on Aptian depositional environments of the Eastern Russian Platform. Palaeogeography, Palaeoclimatology, Palaeoecology 441, 599-609. DOI 10.1016/j.palaeo.2015.08.035

ZorinA, S. 2019. Early Cretaceous microbiofacies and paleobathymetry in the Eastern Russian Platform, 288-292. In Nourgaliev, D.K. (ed.) Sedimentary Earth Systems: Stratigraphy, Geochronology, Petroleum Resources. Proceedings Kazan Golovkinsky Stratigraphic Meeting, 2019. Filodiritto Editore - Proceedings.

Zorina, S.O. \& Startseva, G.N. 2010. Biofacies of benthic foraminifers and paleobathymetry and sequence stratigraphy of Middle Jurassic-Lower Cretaceous deposits on the eastern Russian Plate (area of the Tatarsko-Shatrashanskaya 1 borehole, Republic of Tatarstan), Litosfera 4, 81-93.

Zorina, S.O., Pavlova, O.V., Galiullin, B.M., Morozov, V.P. \& EsKIn, A.A. 2017. Euxinia as a dominant process during OAE1a (Early Aptian) on the Eastern Russian Platform and during OAE1b (Early Albian) in the Middle Caspian. Science China: Earth Sciences 60, 58-70. DOI 10.1007/s11430-016-0043-1

Zorina, S.O., NiKashin, K.I. \& SoKerin, M.Y. 2020. Geochemical Indicators of "Camouflaged" Pyroclastic Material in the Upper Jurassic-Lower Cretaceous Deposits of the Eastern Russian Platform. Doklady Earth Sciences 493, 608-611. DOI 10.1134/S1028334X2008022X 